NATIONAL LABORATORY

\title{
Advanced Materials in Support of EERE Needs to Advance Clean Energy Technologies Program Implementation
}

September 30, 2013

Prepared by

Hiram Rogers

Alan Liby

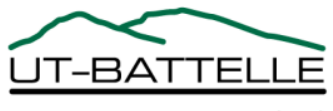




\title{
DOCUMENT AVAILABILITY
}

Reports produced after January 1, 1996, are generally available free via the U.S. Department of Energy (DOE) Information Bridge.

Web site http://www.osti.gov/bridge

Reports produced before January 1, 1996, may be purchased by members of the public from the following source.

\author{
National Technical Information Service \\ 5285 Port Royal Road \\ Springfield, VA 22161 \\ Telephone 703-605-6000 (1-800-553-6847) \\ TDD 703-487-4639 \\ Fax 703-605-6900 \\ E-mail info@ntis.gov \\ Web site http://www.ntis.gov/support/ordernowabout.htm
}

Reports are available to DOE employees, DOE contractors, Energy Technology Data Exchange (ETDE) representatives, and International Nuclear Information System (INIS) representatives from the following source.

Office of Scientific and Technical Information

P.O. Box 62

Oak Ridge, TN 37831

Telephone 865-576-8401

Fax 865-576-5728

E-mail reports@osti.gov

Web site http://www.osti.gov/contact.html

This report was prepared as an account of work sponsored by an agency of the United States Government. Neither the United States Government nor any agency thereof, nor any of their employees, makes any warranty, express or implied, or assumes any legal liability or responsibility for the accuracy, completeness, or usefulness of any information, apparatus, product, or process disclosed, or represents that its use would not infringe privately owned rights. Reference herein to any specific commercial product, process, or service by trade name, trademark, manufacturer, or otherwise, does not necessarily constitute or imply its endorsement, recommendation, or favoring by the United States Government or any agency thereof. The views and opinions of authors expressed herein do not necessarily state or reflect those of the United States Government or any agency thereof. 
Advanced Manufacturing Office

\title{
Advanced Materials in Support of EERE Needs to Advance Clean Energy Technologies Program Implementation
}

August 31, 2009 to September 30, 2013

\author{
Authors \\ Hiram Rogers \\ 865-576-9595 \\ rogersjh@ornl.gov \\ Alan Liby \\ 865-576-4221 \\ libyal@ornl.gov
}

Date Published: September, 2013

\author{
Prepared by \\ OAK RIDGE NATIONAL LABORATORY \\ Oak Ridge, Tennessee 37831-6283 \\ managed by \\ UT-BATTELLE, LLC \\ for the \\ U.S. DEPARTMENT OF ENERGY \\ under contract DE-AC05-00OR22725
}





\section{CONTENTS}

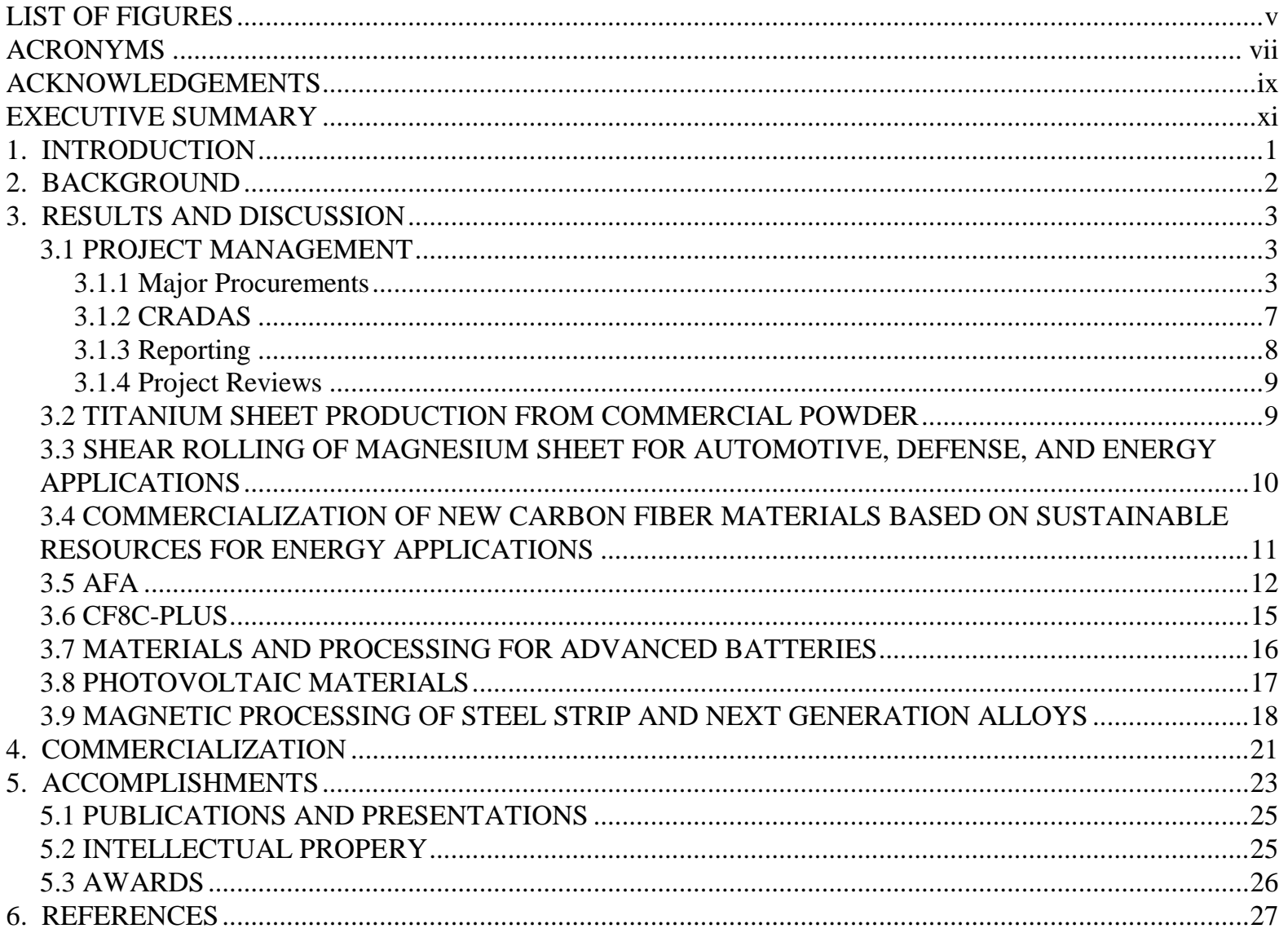





\section{LIST OF FIGURES}

Fig. 1. ORNL's 7 inch wide roll compaction mill with 17 inch diameter rolls.

Fig. 2. The new asymmetric rolling mill designed and fabricated by FATA Hunter in collaboration with ORNL received a 2012 R\&D 100 award.

Fig. 3. ORNL Mesh Belt Furnace .......................................................................................................

Fig.4. Commercialization effort overview of baseline AFA OC4 alloy processing and component manufacture. .5

Fig. 5. CF8C-Plus casting of turbine housing at foundry and upon delivery to Solar Turbines..........................6

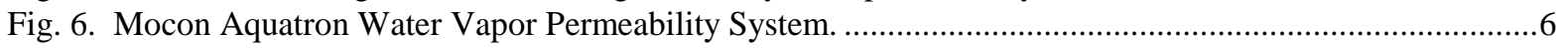

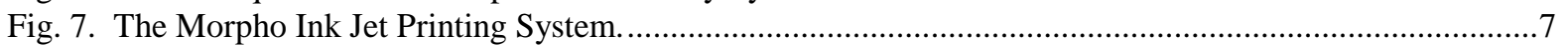

Fig. 8. Dual-chamber (sputtering and thermal evaporation) system for CdTe research.................................

Fig. 9. Announcement of Collaborative Research Opportunity. ..........................................................

Fig. 10. Three-flow heat exchanger in the test bay at Campbell Applied Physics.........................................10

Fig. 11. Photograph showing firewall parts formed at Superform...............................................................11

Fig. 12. Fuel cap filter formed at Superform for General Motors from shear rolled ZEK100..........................11

Fig. 13. 18" diameter thermal insulation prototypes fabricated from LBCF (GrafTech photo) ...........................12

Fig. 14. Cast ingot of AFA $(10,000 \mathrm{lb})$ at Carpenter Technology Corp. ........................................................13

Fig. 15. Sample of folded AFA foil, 8 " wide, produced by Capstone Turbine Corp.....................................13

Fig. 16. Piece of folded AFA OC4 foil from Solar Turbines, Inc..............................................................13

Fig. 17. Braze joint showing excellent joining of AFA foil (left) and subscale heat exchanger with folded AFA foil (right).

Fig. 18. Update on the Solar Turbines demonstration at a CHP project in California. The CF8C-Plus housing is

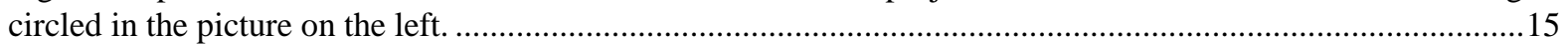

Fig. 19. Keel bars and tube sections from the two commercial orders of CF8C-Plus........................................15

Fig. 20. Rolls of SYMMETRIX ${ }^{\circledR}$ HPX-4 (unfilled) and HPX-F (ceramic-filled) separators for lithium ion batteries.

Fig. 21. Top row: digital images of CIGS films acquired via different deposition techniques: spin coating, drop casting, and sono-spray deposition. Bottom row: microscope images showing the morphology of the films over a $2.5 \mathrm{~mm}$ square area.

Fig. 22. CdTe thin film solar device array on Kapton disc.

Fig. 23. Typical ferrous alloy components (left to right: large torsion fatigue sample, orbital drive, small torsion fatigue sample, gear) that would need to be handled by the commercial prototype system at insertion rates up to 10 inches/s while under a 9 tesla magnet field.

Fig. 24. World's first commercial prototype H\&TMP/EMAT system with an $\sim 8$-inch diameter, vertical warm bore superconducting magnet system and $200 \mathrm{KW}$ dual-frequency induction heating system. 



\section{ACRONYMS}

AFA

AMI

AMO

ARRA

ASME

ASTM

ATI

CHP

CIGS

CRADA

DOE

EERE

EMAT

$\mathrm{HDH}$

H\&TMP

IMF

ITMP

ITP

LIB

$\mathrm{LBCF}$

LBIC

MCMB

MENA

NMCA

ORNL

OSTI

PL

PVDF

R\&D

SPEED

SF\&E

US

UV/IR
Alumina-forming Austenitic

American Magnetics Inc.

Advanced Manufacturing Office

American Recovery and Reinvestment Act

American Society of Mechanical Engineers

American Standards for Testing Materials

AjaxTOCCO Magnethermic

Combined Heat and Power

Copper Indium Gallium diSelenide

Cooperative Research and Development Agreement

Department of Energy

Office of Energy Efficiency and Renewable Energy

Electro-Magnetic Acoustic Transducer

Hydride Dehydride

High and Thermal Magnetic Processing

Industrial Materials for the Future

Induction Thermomagnetic Processing

Industrial Technologies Program

Lithium Ion Battery

Lignin-based Carbon Fibers

Light Beam Induced Current

Mesoporous Carbon Microbeads

Magnesium Elektron North America

$\mathrm{LiNi}_{\mathrm{x}} \mathrm{Mn}_{\mathrm{y}} \mathrm{Co}_{\mathrm{z}} \mathrm{Al}_{1-\mathrm{x}-\mathrm{y}-\mathrm{z}} \mathrm{O}_{2}$

Oak Ridge National Laboratory

Office of Science and Technology Information

Photoluminesence

Poly(Vinylidene Fluoride)

Research and Development

Streaming Process for Electroless Electrochemical Deposition

Stainless Foundry \& Engineering

United States

Ultraviolet/Infrared 


\section{ACKNOWLEDGEMENTS}

This report is based upon work supported by the Advanced Manufacturing Office (AMO) of the U. S. Department of Energy (DOE) under CPS Agreement 20360 via the Advanced Materials R\&D in Support of EERE Needs to Advance Clean Energy Technologies Program of the American Recovery and Reinvestment Act (ARRA) of 2009. 


\section{EXECUTIVE SUMMARY}

This report summarizes the program management activities for the ARRA-funded Advanced Materials in Support of EERE Needs to Advance Clean Energy Technologies sponsored by the DOE Advanced Manufacturing Office (AMO), formerly the Industrial Technologies Program (ITP). Program management activities included guidance of the technical programs, assistance with major procurements, assistance with open announcements and selection of industry partners for commercial demonstrations, development of commercialization activities, reporting of status and results to DOE headquarters and annual progress reviews.

The work was organized into eight projects the strategic materials titanium, magnesium and carbon fiber, structural materials including alumina forming austentic (AFA) and CF8C-Plus steels, materials for energy storage, materials for photovoltaic solar energy production, and advanced/field/transient materials processing. Details of the results of each of the activities under Advanced Materials in Support of EERE Needs to Advance Clean Energy Technologies are discussed in the final reports for those activities. 


\section{INTRODUCTION}

The goal of this activity was to carry out program implementation and technical projects in support of the ARRA-funded Advanced Materials in Support of EERE Needs to Advance Clean Energy Technologies Program of the DOE Advanced Manufacturing Office (AMO) (formerly the Industrial Technologies Program (ITP)).

The work was organized into eight projects in four materials areas: strategic materials, structural materials, energy storage and production materials, and advanced/field/transient processing. Strategic materials included work on titanium, magnesium and carbon fiber. Structural materials included work on alumina forming austentic (AFA) and CF8C-Plus steels. The advanced batteries and production materials projects included work on advanced batteries and photovoltaic devices.

Advanced/field/transient processing included work on magnetic field processing. Details of the work in the eight projects are available in the project final reports which have been previously submitted.

This effort focused on program implementation and support activities. These activities were concentrated heavily on the procurement and subcontracting activities needed to develop the equipment capabilities and teaming arrangements needed to accelerate the commercialization of the technologies. As the projects matured, the effort focus shifted to ensuring that project milestones were met, supporting the technical and financial reporting requirements, and meeting project review requirements. 


\section{BACKGROUND}

The goal of this project was to carry out program implementation and technical projects in support of the ARRA-funded Advanced Materials in Support of EERE Needs to Advance Clean Energy Technologies Program of the DOE Advanced Manufacturing Office (AMO) (formerly the Industrial Technologies Program (ITP)).

This effort provided program management support for the ARRA-funded Advanced Manufacturing Office (formerly the Industrial Technologies Program) Advanced Materials in Support of EERE Needs to Advance Clean Energy Technologies Program. Activities included coordination of financial and technical reporting, response to headquarters information requests, analyses of program opportunities and benefits, information materials and reports, and coordination and transfer of technology through portfolio and focus area reviews. Early efforts were concentrated in managing and accelerating the critical capital procurements, subcontracts and CRADAs essential to the advancement of these programs. Other project management activities included managing quarterly reporting to DOE HQ and developing a project tracking database to determine monthly progress. 


\section{RESULTS AND DISCUSSION}

This effort involved the program management of eight research and development (R\&D) activities. Project management activities are described first, followed by brief summaries of the R\&D activities.

\subsection{PROJECT MANAGEMENT}

Early efforts were concentrated in managing and accelerating the critical capital procurements, subcontracts and CRADAs essential to the advancement of these programs. Other project management activities included managing quarterly reporting to DOE HQ and developing a project tracking database to determine monthly progress.

Monthly spend plans for the subcontracts, capital procurements, and CRADA's that are committed in the Advanced Materials ARRA funding were compiled.

As the result of determination by the Office of Information and Business, several program milestones were revised to meet the SMART (specific, measurable, achievable, relevant, and time-based) criteria.

\subsubsection{Major Procurements}

A roll compaction mill (Fig. 1) for the titanium powder was procured. A subcontract for retooling a used 7 inch wide roll compaction mill for use with titanium powders was issued to International Rolling Mills, Pawtucket, RI. The mill was delivered and installed.

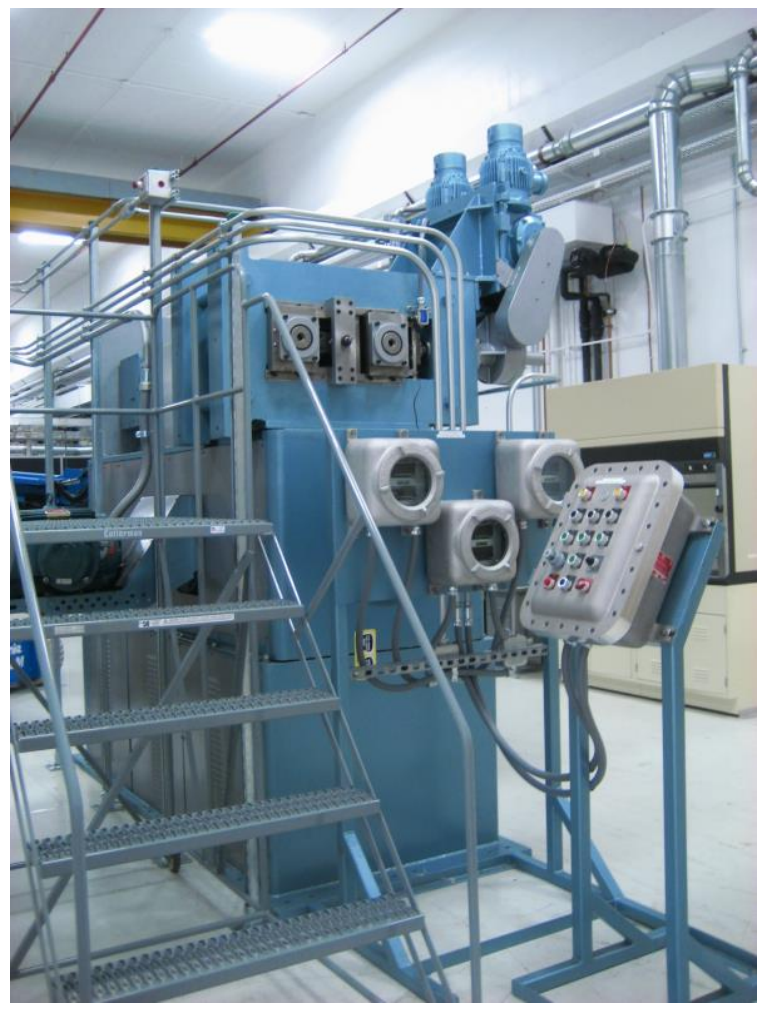

Fig. 1. ORNL's 7 inch wide roll compaction mill with 17 inch diameter rolls. 
The shear rolling mill (Fig. 2) for the magnesium project was installed and operated starting in June 2012. Operation of the shear rolling mill completed the capital acquisitions for the ARRA materials projects.

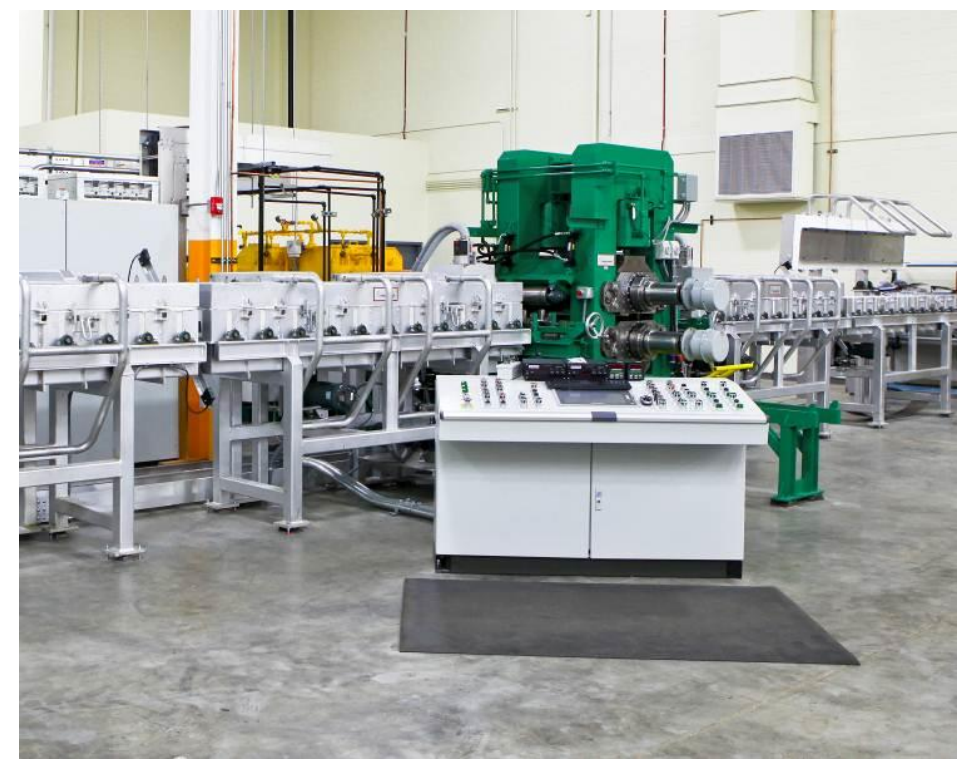

Fig. 2. The new asymmetric rolling mill designed and fabricated by FATA Hunter in collaboration with ORNL received a $2012 \mathrm{R} \& D 100$ award.

For the carbon fiber project, a dual-mode Harper Rotary Kiln/Mesh Belt furnace for the carbon fiber project was commissioned (Fig. 3). Change out of the furnace from tube mode to mesh belt mode was completed, and the operation of the mesh belt was confirmed at belt speeds and temperatures suitable for stabilization and carbonization. The belt was shown to operate at 10 inches per hour and at 60 inches per hour at both $250 \mathrm{C}$ and $800 \mathrm{C}$, completing the requirements for that equipment. The furnace itself is capable of $1000 \mathrm{C}$ temperature and variable belt speeds of 8-80 inches per hour.

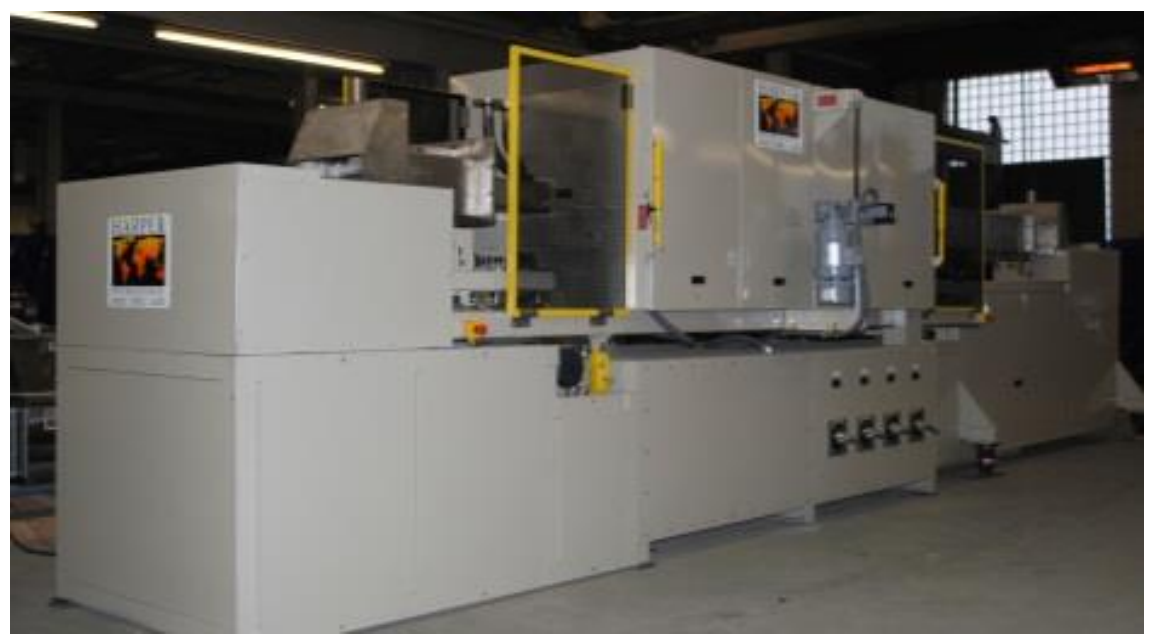

Fig. 3. ORNL Mesh Belt Furnace

The commercial demonstrations for AFA included an open solicitation process for industrial demonstration of AFA components in various applications (Fig.4) . Capstone Turbine Corporation 
was selected for demonstration of AFA alloy recuperators for their high efficiency microturbines. United Technologies Corp. and partner University of Connecticut were selected for evaluation of AFA alloys for solid oxide fuel cell balance of plant heat exchangers. An additional demonstration effort was initiated with Solar Turbines, Inc. for evaluation of AFA alloys for use as a recuperator in their Mercury 50 4.6MW turbine gas turbine. Carpenter Technology Corporation, a leading US specialty alloy manufacturer, licensed the AFA alloy family on April 7, 2011 and participated in scale up activities, including manufacture of $400 \mathrm{lb}$ trial heats and a 10,000 lb production heat, which was used to supply AFA material to industrial partners for evaluation.

\section{AFA Commercialization: 0C4 Products}

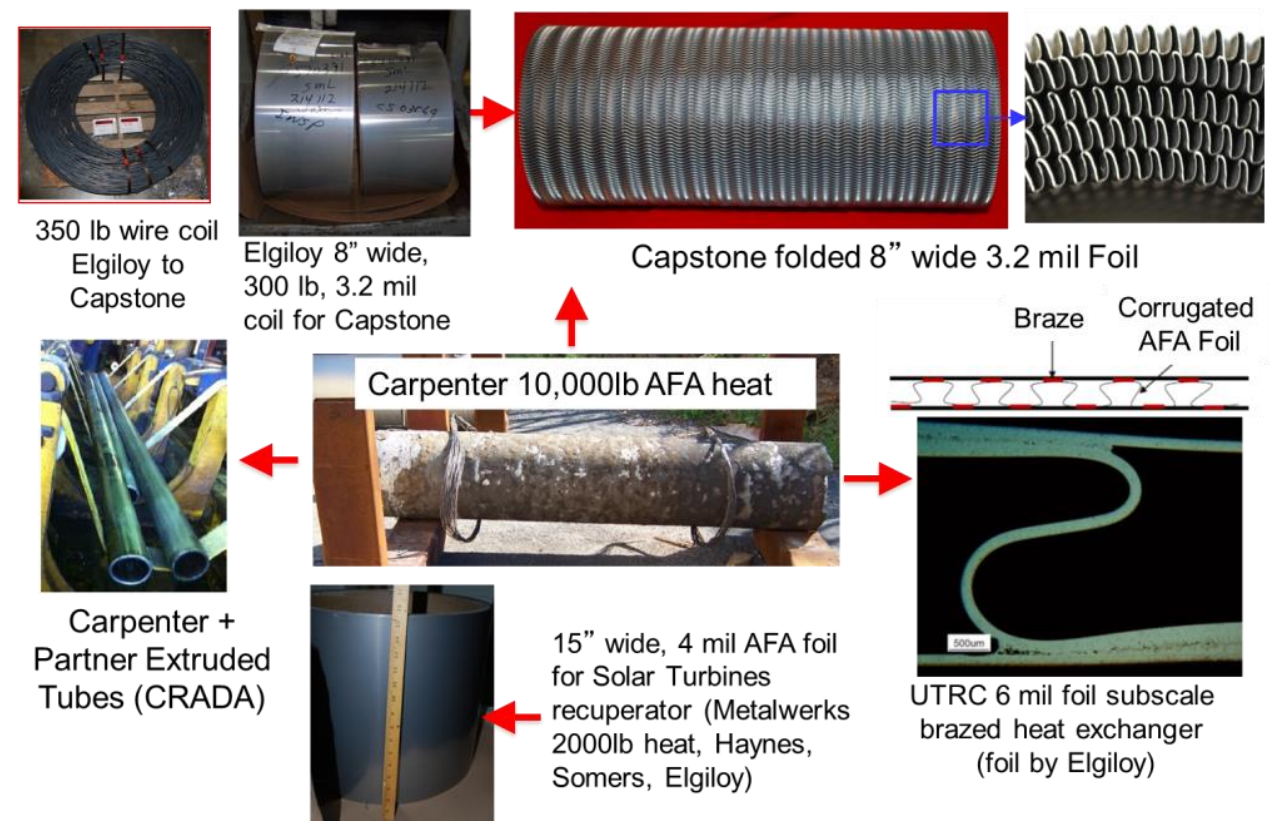

Fig.4. Commercialization effort overview of baseline AFA OC4 alloy processing and component manufacture.

In late 2009, an expression of interest was released on FedBizOps to advertise the funding opportunity for commercial demonstration of CF8C-Pluss to all interested parties. One proposal was received from Solar Turbines Inc. in January 2010 and was finalized in August 2010 for a cost shared demonstration of CF8C-Plus as a combustor housing for a 4.6MW Mercury 50 turbine engine. For the Solar Turbines project, two CF8C-Plus housings were fabricated by Wisconsin Centrifugal, Figure 5. The semi-machined weight of each was $\sim 2,620 \mathrm{lbs}$ and both were delivered to Solar Turbines in April 2011. The second casting was cut up for mechanical testing. 

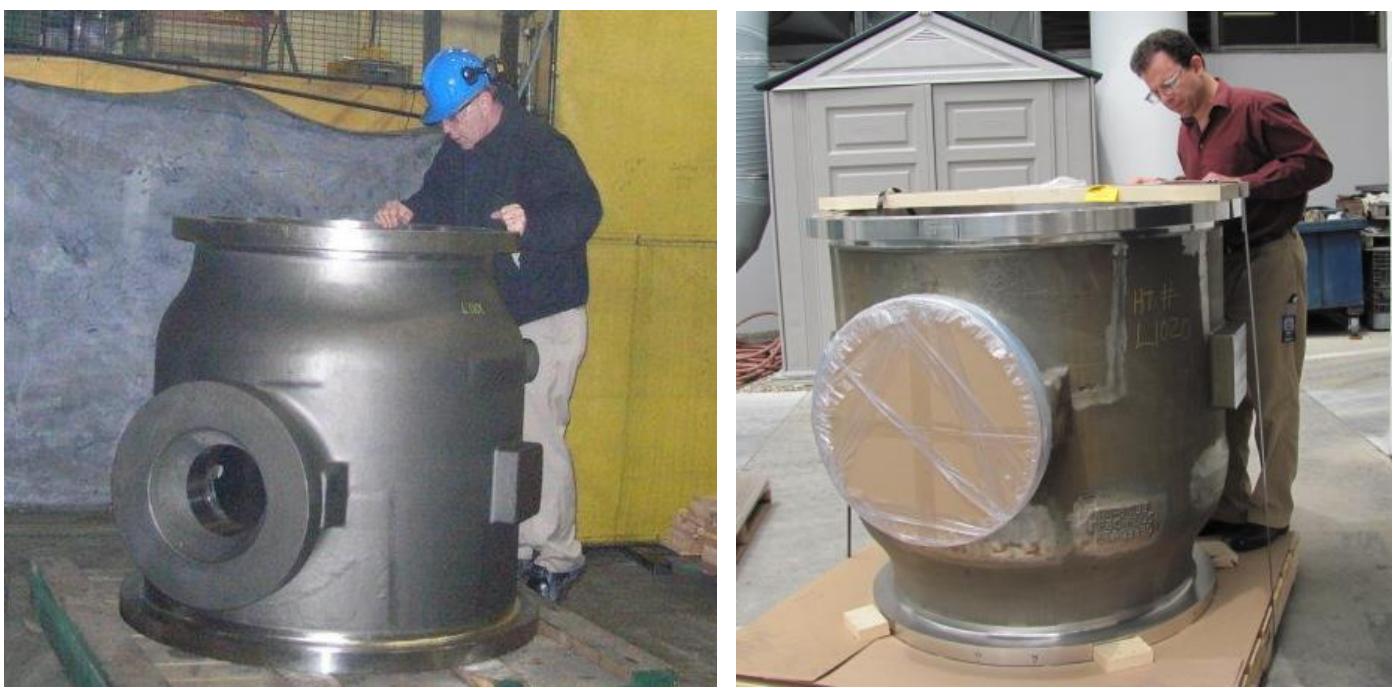

Fig. 5. CF8C-Plus casting of turbine housing at foundry and upon delivery to Solar Turbines.

The Mercury 50 engine with the CF8C-Plus housing was assembled and delivered to the 29 Palms U.S. Marine Corp Base in California for a CHP expansion project in late 2011, Figure 4. After a 1.5 year delay in the original project schedule, the CHP project finished hot commissioning in April 2013 and commercial operation is expected after September 2013.

As part of the photovoltaic materials project, ORNL added specific pieces of equipment to enhance our ability to provide unique insight for the solar industry (Fig. 6-8). These capabilities include a moisture barrier measurement system, a combined physical vapor deposition and sputtering system dedicated to cadmium-containing deposits, a deep level transient spectroscopy system useful for identifying defects, an integrating sphere photoluminescence system, and a high-speed ink jet printing system. These tools were combined with others to study the effect of defects on the performance of crystalline silicon and thin film solar cells, to explore non-vacuum ink-based approaches to solar cell production, as well as large-scale and low-cost deposition and processing of thin film CdTe material.

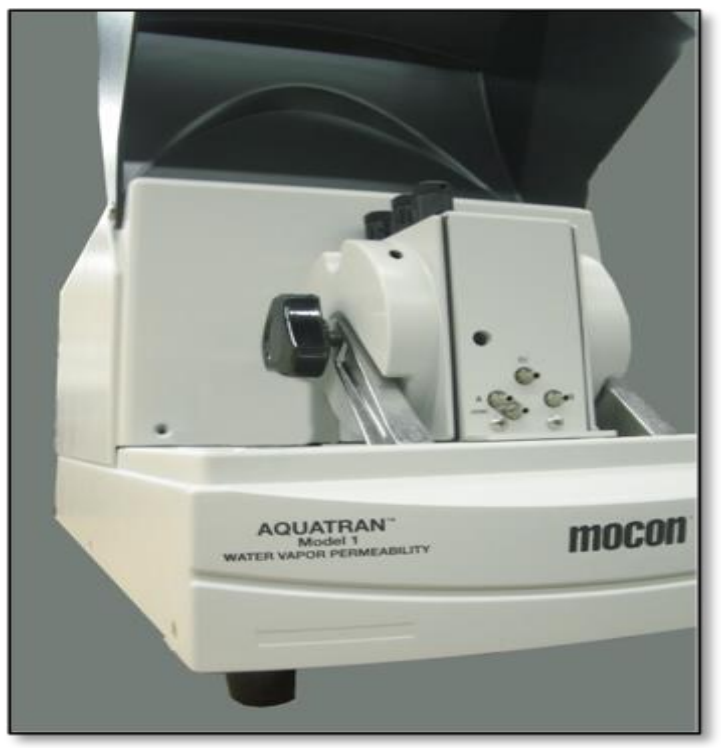

Fig. 6. Mocon Aquatron Water Vapor Permeability System. 


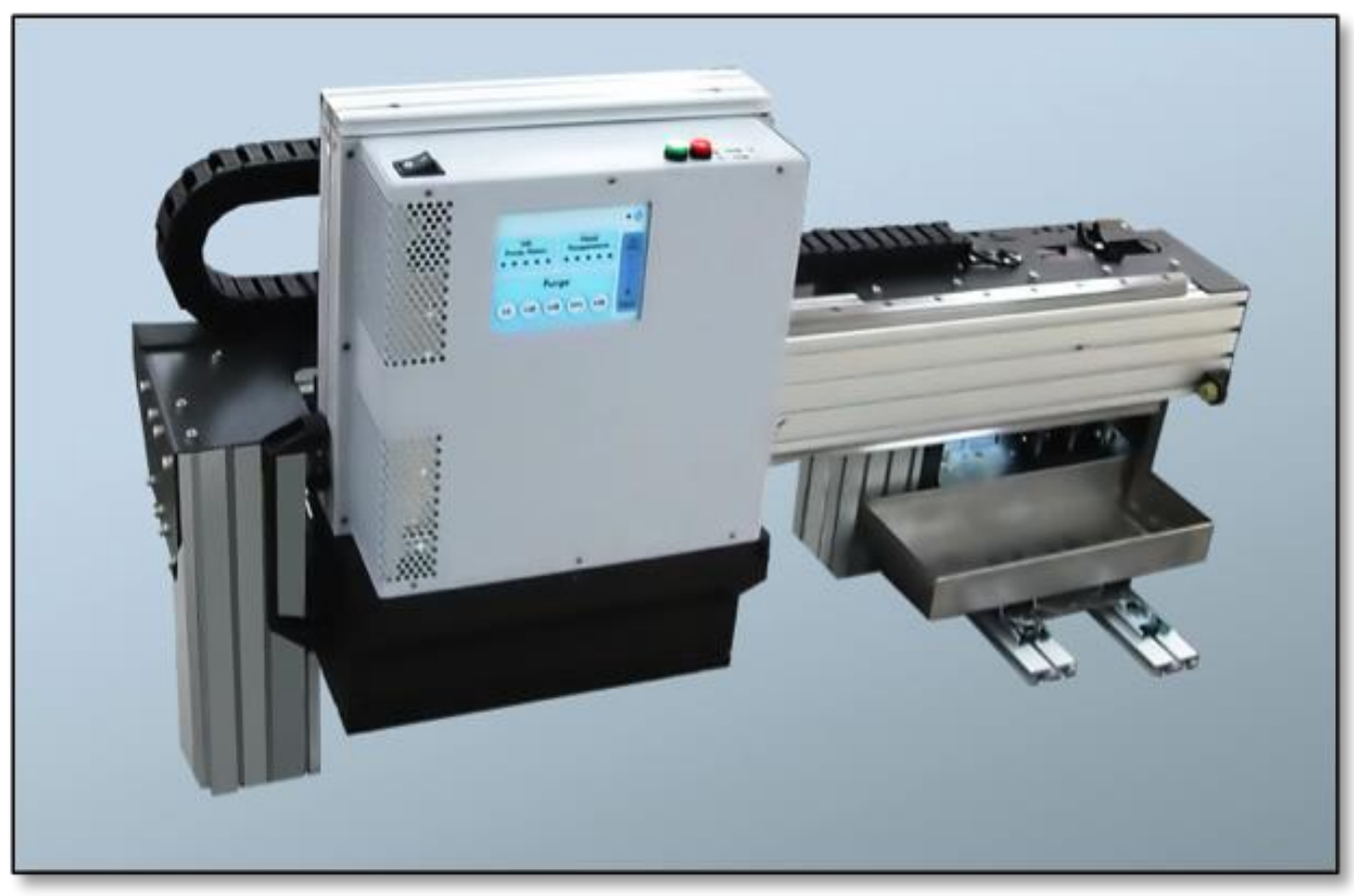

Fig. 7. The Morpho Ink Jet Printing System.

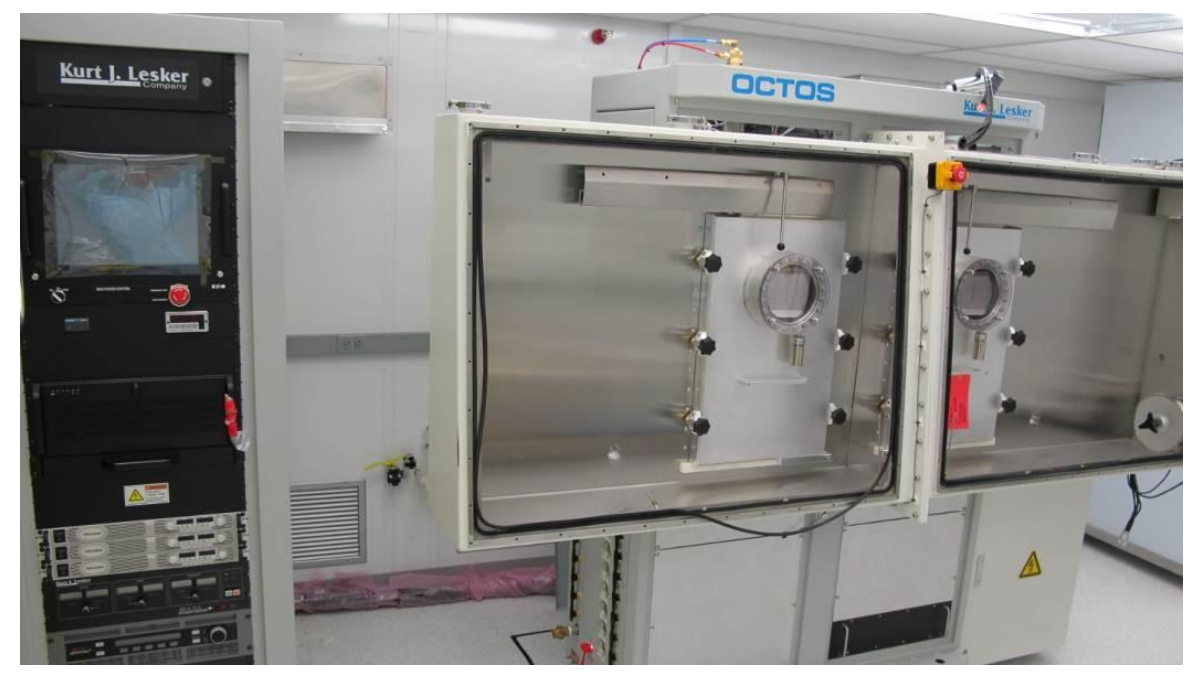

Fig. 8. Dual-chamber (sputtering and thermal evaporation) system for CdTe research.

\subsubsection{CRADAS}

For the advanced batteries project strategic manufacturers were selected through a competitive solicitation issued in late 2009. After the proposal review process individual Cooperative Research and Development Agreements (CRADAs) were signed for the winning proposals. The CRADA between A123 Systems and ORNL addressed the need for low-cost anode active material for lithium ion batteries by lowering the heat-treatment temperature and thermal budget associated with processing natural graphite. A CRADA between Dow Kokam and ORNL addressed critical electrode materials characterization and electrode processing quality control during the initial phase of Dow Kokam's 
existence. ORNL was able to characterize (microstructural, microscopy, and chemical analysis) key active materials and conductive additives, which enabled Dow Kokam to establish confidence in their supply chain. The CRADA between Planar Energy Devices and ORNL combined the innovative materials processing technologies of the room-temperature SPEED (aqueous spray atomization) film deposition process and ORNL's photonic pulse thermal processing to achieve recrystallization and annealing in solid-state cathodes for lithium ion batteries. Porous Power Technologies and ORNL codeveloped a variety of methods during this CRADA to address lithium ion battery separator thermomechanical property characterization and benchmarking to commercially available polyolefin baselines.

For the photovoltaic materials project an early task was to establish a mechanism for industry members to leverage the capabilities at ORNL for advancing the manufacturing of photovoltaic technologies. ORNL announced a Collaborative Research Opportunity in the fall of 2010 that would allow selected companies to engage in a Cooperative Research and Development Agreement (CRADA) with ORNL (Fig. 9). These projects were initiated in the spring of 2011 and lasted of one year. The four projects selected were with Mossey Creek Solar, for producing low-cost high-quality silicon wafers with significant reductions in waste material and energy consumption; Global Solar Energy, for developing scalable non-vacuum deposition techniques for thin-film copper indium gallium diselenide, a directbandgap material for solar cells; Ferro Corp., for developing inks and pastes to be used for highly conductive layers in thin-film solar cell applications; and Ampulse, for developing an efficient roll-toroll manufacturing process to deposit thin-film silicon.

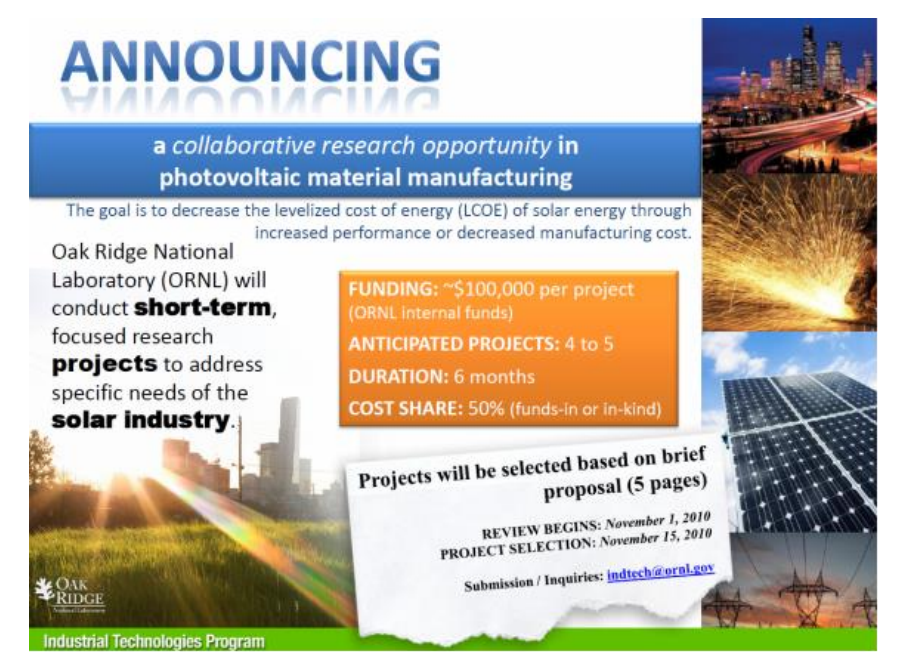

Fig. 9. Announcement of Collaborative Research Opportunity.

\subsubsection{Reporting}

Quarterly technical reports were submitted to DOE headquarters for each project through the duration of the project. Quarterly reports for the project management activity were also submitted.

ARRA quarterly highlights were submitted through the ORNL Primavera system for posting to recovery.org through the duration of the projects.

Final reports for all the projects have been submitted to DOE headquarters. All final reports were prepared in the format of ORNL technical reports and are stored in the ORNL publications tracking 
system. The reports have also been sent to the Office of Science and Technology Information (OSTI) database and are available at www.osti.gov.

\subsubsection{Project Reviews}

Annual project reviews were held for this activity.

ORNL hosted a review of ARRA Materials projects for former DOE technical headquarters manager Chien-Wei Li on March 29-30, 2010 as part of a review of all of ORNL's ARRA funded projects sponsored by the Advanced Manufacturing Office.

ORNL hosted a review of ARRA Materials projects for former DOE project monitor Mahesh Jha from the Golden Field office on June 3-4, 2010 as part of a review of all of ORNL's ARRA funded materials projects sponsored by the Advanced Manufacturing Office.

A DOE headquarters review of the Advanced Materials in Support of EERE Needs to Advance Clean Energy Technologies and Industrial Materials of the Future (IMF) programs were held at ORNL on May 4-5, 2011. The review was attended by Leo Christodoulou - former AMO Program Manager, Jamie Link - former Deputy AMO Program Manager, Steve Sikirica - Materials Portfolio Manager, and Mahesh Jha - former Project Manager.

A review of the entire Advanced Materials in Support of EERE Needs to Advance Clean Energy Technologies Program was held at ORNL from September, 10-12 2012 for Steve Sikirica - Materials Portfolio Manager from DOE HQ and Mahesh Jha - former Project Manager from the Golden Field Office.

\subsection{TITANIUM SHEET PRODUCTION FROM COMMERCIAL POWDER}

Powder metallurgy titanium sheet was produced from hydride dehydride (HDH) powder using a diverse industrial supply chain. Three different processing routes were developed and production protocols were established in each route to provide options for manufacturing sheet. The produced sheet was tested in accordance with American Society for Testing and Materials (ASTM) B265 specifications and found to be equivalent with grade 4 in yield strength and tensile strength and were at grade 2 levels for elongation. The produced sheet was tested in a newly designed flat plate heat exchanger (Fig. 10) specifically designed for enhanced reverse osmosis desalination. The powder metallurgy sheet was found to be equivalent in performance to commercially available sheet produced by the standard Kroll process. The testing allows for an alternate supply chain for thin gage titanium sheet to be developed that is not based on the often volatile, aerospace supply chain. 


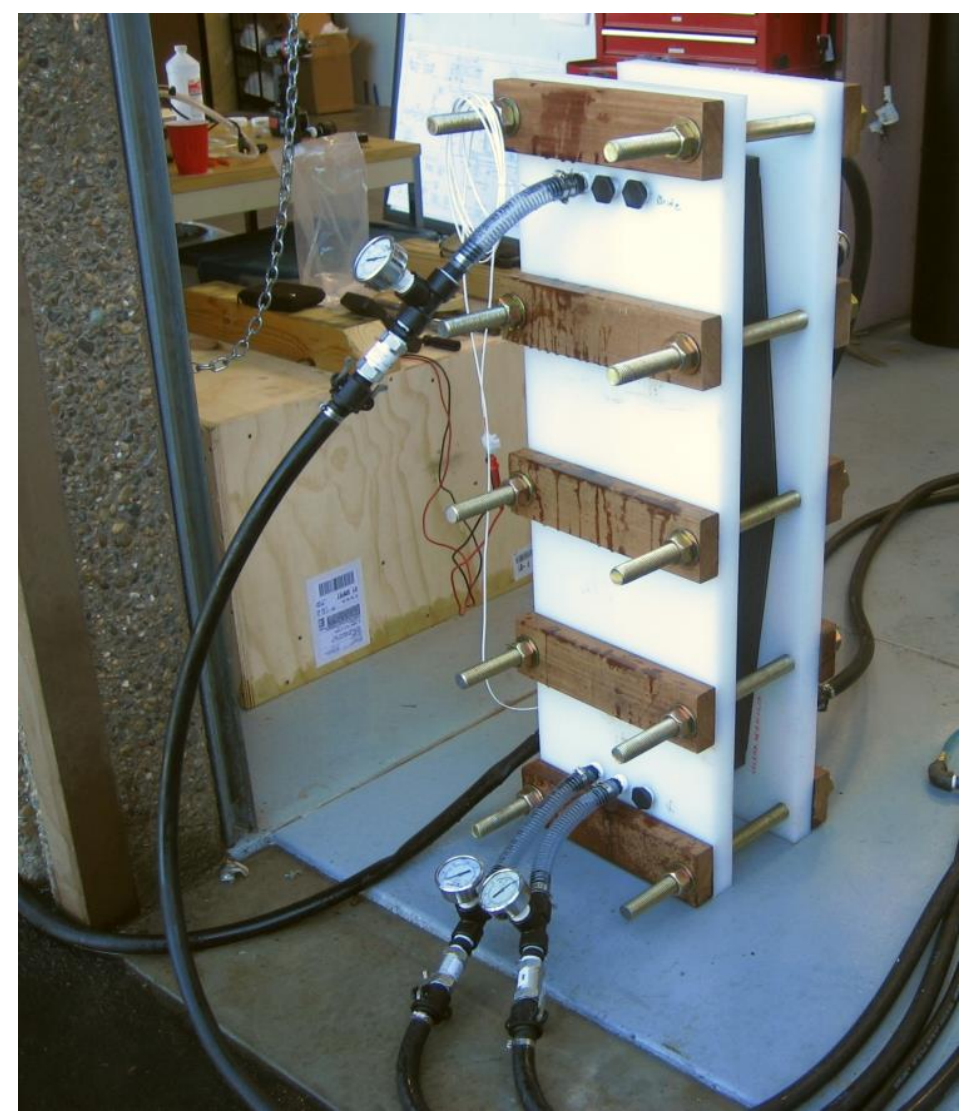

Fig. 10. Three-flow heat exchanger in the test bay at Campbell Applied Physics.

\subsection{SHEAR ROLLING OF MAGNESIUM SHEET FOR AUTOMOTIVE, DEFENSE, AND ENERGY APPLICATIONS}

- Laboratory-scale asymmetric rolling of shear rolling of magnesium sheet was demonstrated using 3:1 rolls producing 2 -inch wide sheet with modified texture

- Tilting of basal poles away from the sheet normal direction was clearly demonstrated by asymmetric rolling

- Eight-inch wide sheet has been rolled at ORNL using the shear rolling mill

- Texture modification using asymmetric rolling was clearly demonstrated for sheet

- Improved formability in biaxial testing was initially demonstrated for specific asymmetric rolling processing conditions.

- An existing industrial scale mill was modified, and the feasibility of shear rolling wide sheet for commercial use was demonstrated at Magnesium Elektron North America (MENA)'s facility

- Two demonstration automotive components, a firewall and a fuel cap filter (fig. 11 and 12), were fabricated using wide sheet manufactured at MENA and fabricated at Superform. 


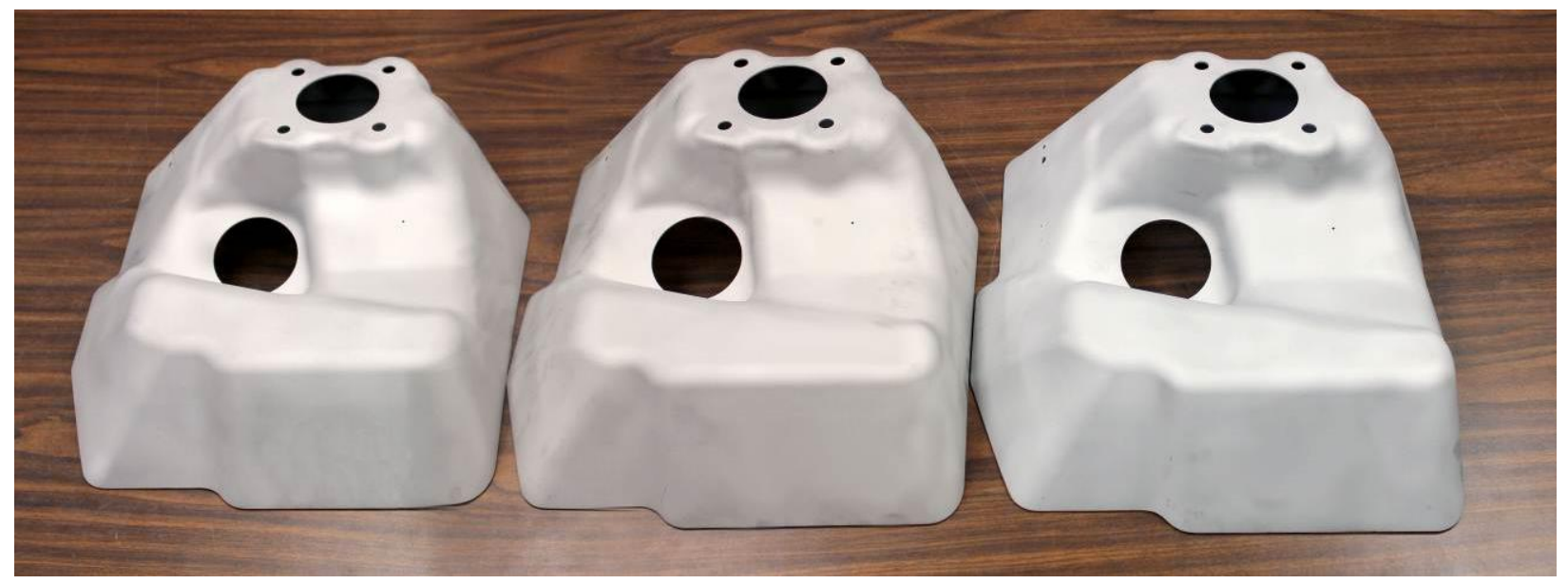

Fig. 11. Photograph showing firewall parts formed at Superform..

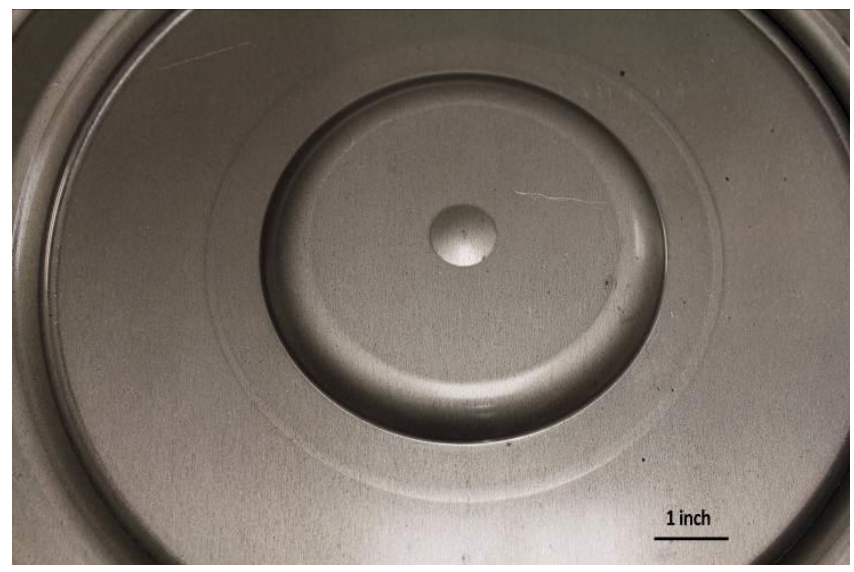

Fig. 12. Fuel cap filter formed at Superform for General Motors from shear rolled ZEK100.

\subsection{COMMERCIALIZATION OF NEW CARBON FIBER MATERIALS BASED ON SUSTAINABLE RESOURCES FOR ENERGY APPLICATIONS}

Oak Ridge National Laboratory (ORNL) and GrafTech International Holdings Inc. (GrafTech) collaborated to develop and demonstrate the performance of high temperature thermal insulation prototypes made from lignin-based carbon fibers (Fig. 13). This project will potentially lead to the first commercial application of lignin-based carbon fibers (LBCF). The goal of the commercial application is to replace expensive, Chinese-sourced isotropic pitch carbon fibers with lower cost carbon fibers made from a domestically sourced, bio-derived (renewable) feedstock. LBCF can help recapture jobs that were previously exported to China while resolving supply chain vulnerability and reducing the production cost for GrafTech's high temperature thermal insulation.

The performance of the LBCF prototypes was measured and found to be comparable to that of the current commercial product. During production of the insulation prototypes, ORNL and GrafTech demonstrated lignin compounding/pelletization, fiber production, heat treatment, and compositing at scales far surpassing those previously demonstrated in LBCF R\&D or production.

The key conclusion of this work is that LBCF thermal insulation performance at the prototype scale is similar to that of commercial thermal insulation made from pitch-based carbon fibers. Technical 
feasibility for the performance of LBCF thermal insulation has been demonstrated. Several "world record" scaling milestones were achieved to demonstrate this performance.

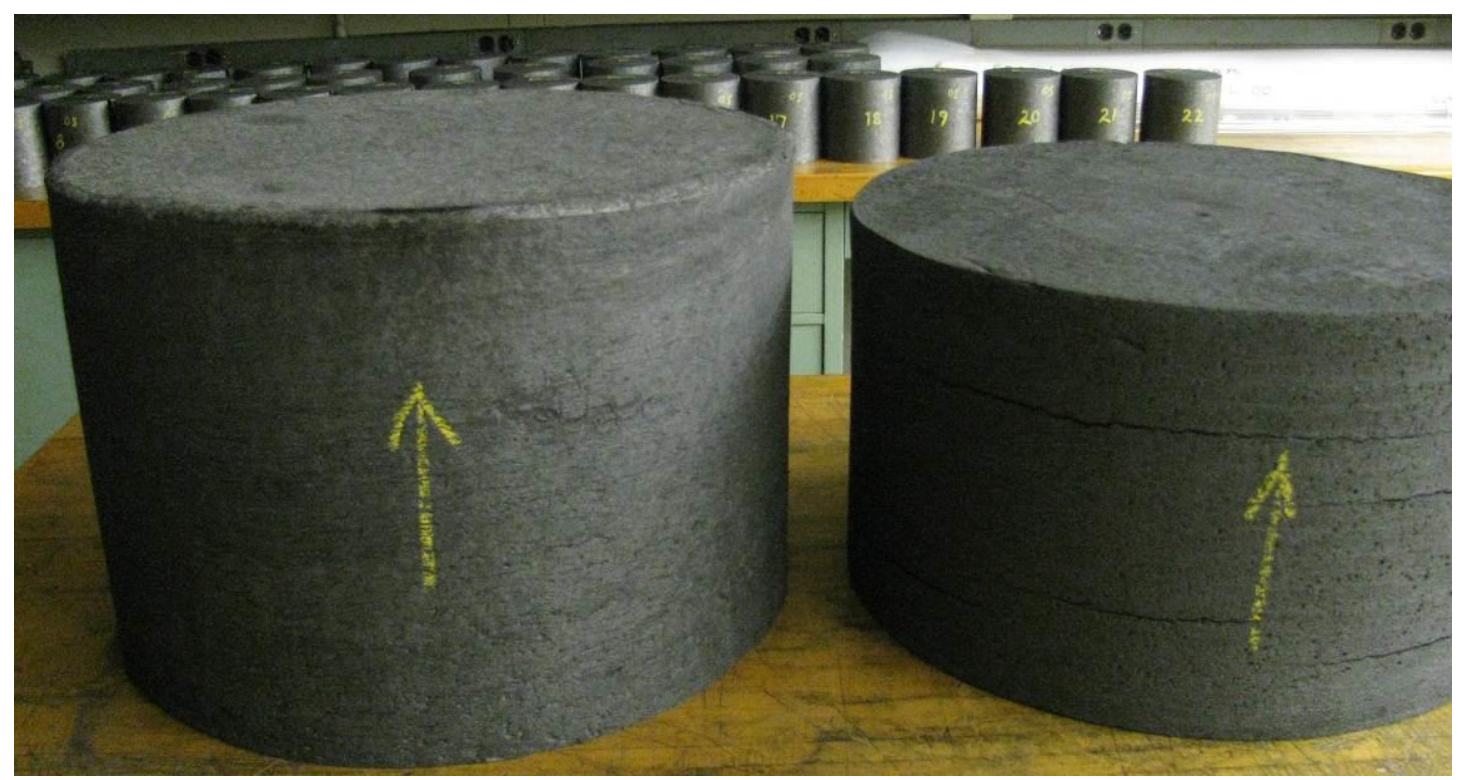

Fig. 13. 18" diameter thermal insulation prototypes fabricated from LBCF (GrafTech photo).

\subsection{AFA}

The purpose of the AFA project was to accelerate the development and deployment of a new family of heat-resistant alloys developed at ORNL: alumina-forming austenitic (AFA) stainless steels. Initial laboratory scale evaluation indicated that the AFA alloys possess exceptional high-temperature oxidation resistance while retaining creep properties similar to other advanced austenitic stainless steels. The AFA steels therefore represent a low-cost alternative to Ni-base alloys and a highperformance alternative to conventional advanced austenitic steels.

Commercial demonstrations of AFA resulted from an open solicitation process for industrial demonstration of AFA components in various applications (Fig. 14). Capstone Turbine Corporation was selected for demonstration of AFA alloy recuperators for their high efficiency microturbines (Fig. 15). United Technologies Corp. and partner University of Connecticut were selected for evaluation of AFA alloys for solid oxide fuel cell balance of plant heat exchangers. An additional demonstration effort was initiated with Solar Turbines, Inc. (Fig. 16) for evaluation of AFA alloys for use as a recuperator in their Mercury 50 4.6MW turbine gas turbine. Carpenter Technology Corporation, a leading US specialty alloy manufacturer, licensed the AFA alloy family on April 7, 2011 and participated in scale up activities, including manufacture of $400 \mathrm{lb}$ trial heats and a 10,000 lb production heat, which was used to supply AFA material to industrial partners for evaluation. 


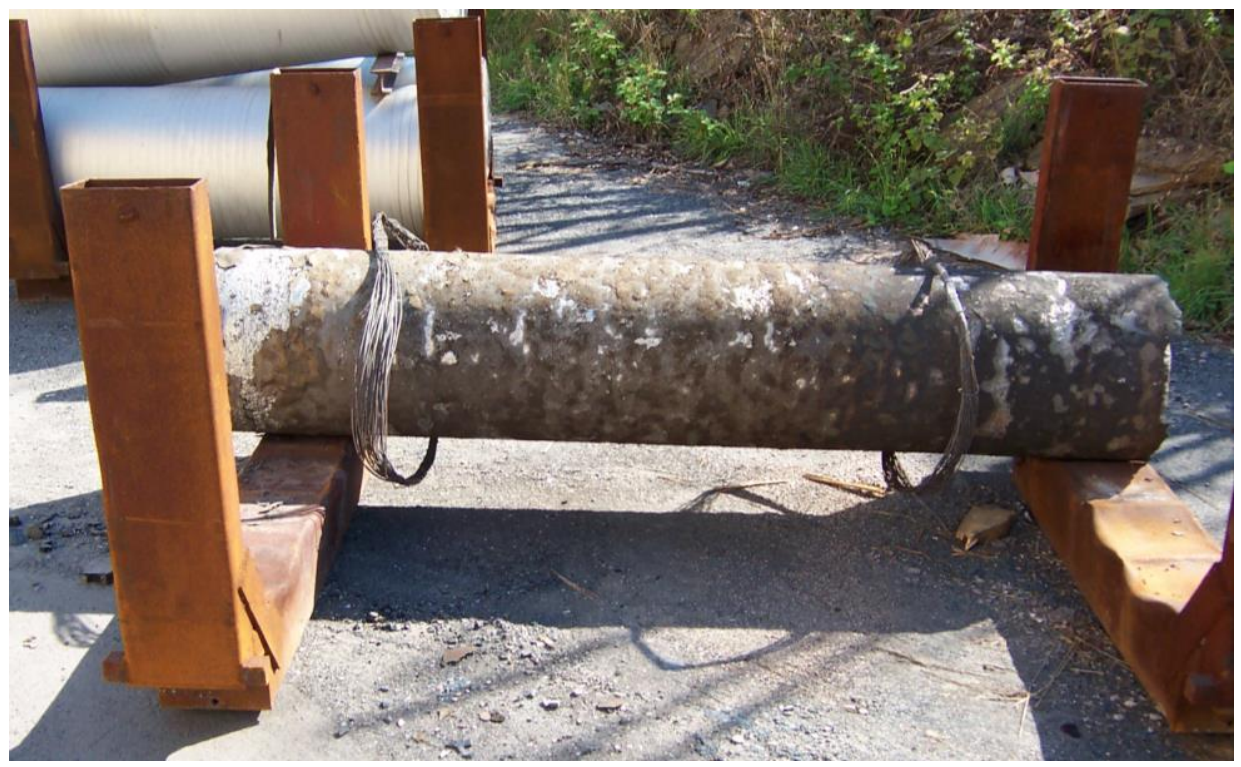

Fig. 14. Cast ingot of AFA (10,000 lb) at Carpenter Technology Corp.

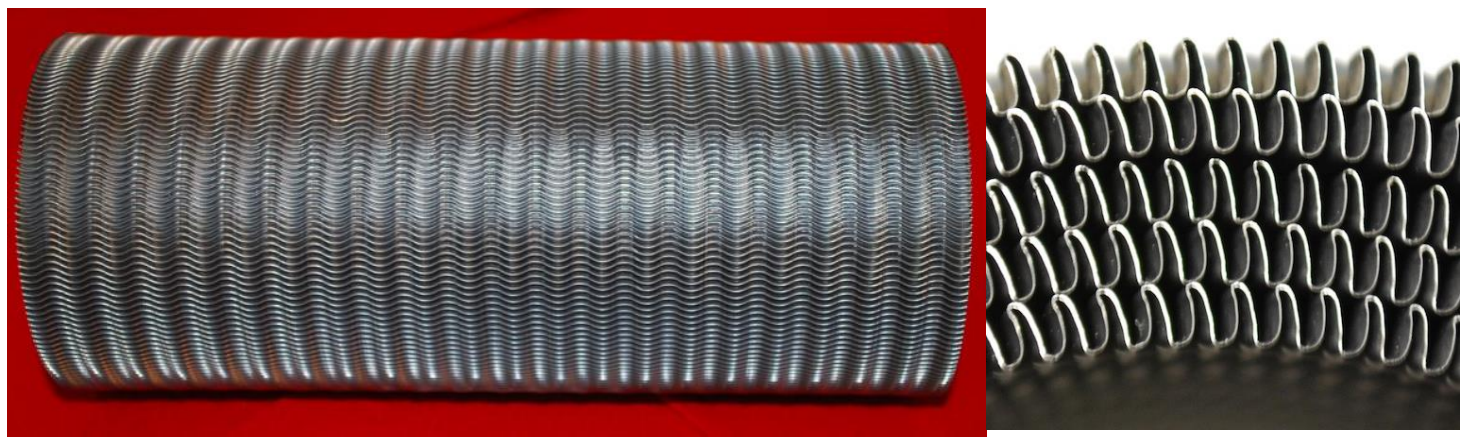

Fig. 15. Sample of folded AFA foil, $\sim 8$ ” wide, produced by Capstone Turbine Corp.

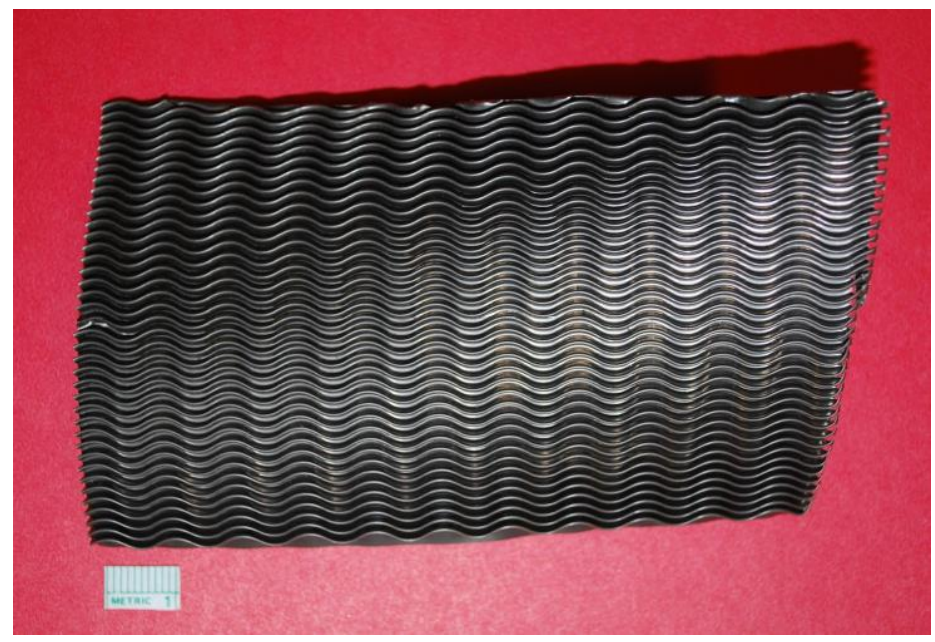

Fig. 16. Piece of folded AFA OC4 foil from Solar Turbines, Inc. 
The primary technical conclusions of the AFA project are:

1) AFA stainless steels are amenable to established commercially used manufacturing methods and can be made in sheet, foil, and tube form (Fig. 17). The alloys generally require high solutionizing temperatures $\left(1200^{\circ} \mathrm{C}\right)$ for amenability to hot/cold working and to achieve optimal creep properties. However, compositions with a good balance of creep and oxidation resistance were also identified that can tolerate lower solutionizing temperatures $\left(1050-1100^{\circ} \mathrm{C}\right)$ more widely attainable at commercial alloy post processors.

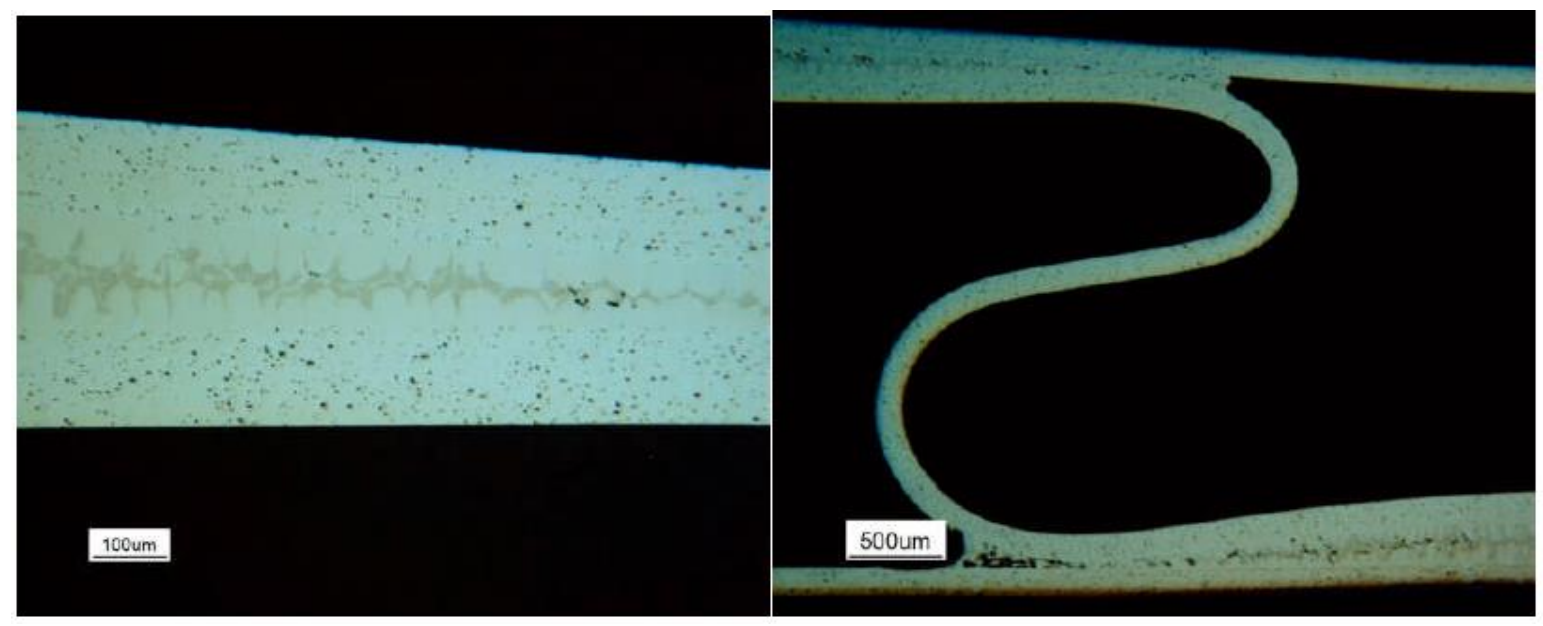

Fig. 17. Braze joint showing excellent joining of AFA foil (left) and subscale heat exchanger with folded AFA foil (right).

2) Surface finish of AFA foil emerged as an issue in foil production, with the high thermodynamic stability of alumina making it difficult to eliminate oxidation during alloy processing. The presence of residual surface oxide on AFA foil complicated joining of foil form material. Commercial foils of other alumina-formers such as the $\mathrm{FeCrAl}$ class of alloys are available, and techniques used for those materials to produce a "shiny" oxide free surface finish should be adopted for AFA alloy foil product.

3) The AFA alloy family in bulk sheet/plate form is readily weldable by conventional means with little detrimental impact on creep resistance.

4) A grade of AFA amenable to use in the as-cast form was successfully developed, and opens up consideration of AFA for a wide range of cast components, in addition to in initially developed wrought forms.

5) The AFA alloys are most suited to applications involving high temperature exposure to water vapor, steam, and $\mathrm{C}$ and/or $\mathrm{S}$ species containing process environments. AFA showed mixed corrosion resistance results in molten salts and hot corrosion conditions, and generally poor resistance in metal dusting conditions. A possible exception to metal dusting resistance is the low $\mathrm{Ni}$, low cost AFALN grade of alloys, which in preliminary testing by an industrial collaborator showed good promise.

6) Multiple grades of AFA alloys are possible, including the baseline AFA grade which provides corrosion resistance up to $700-850^{\circ} \mathrm{C}$; cast AFA for use up to700-850 ${ }^{\circ} \mathrm{C}$; $\square$ '-Ni3Al strengthened AFA superalloy for use up to $700-850^{\circ} \mathrm{C}$ with improved creep strength; AFAHP high performance 
grade, with $\mathrm{Hf}, \mathrm{Zr}$, $\mathrm{Y}$ additions and higher $\mathrm{Al}, \mathrm{Cr}, \mathrm{Nb}$, and $\mathrm{Ni}$ levels permitting use up to $950^{\circ} \mathrm{C}$ range; and low cost AFALN for use up to $650^{\circ} \mathrm{C}$ range.

\subsection{CF8C-PLUS}

A deployment project was initiated for a new cast austenitic stainless steel, CF8C-Plus, which was jointly developed by Caterpillar and ORNL. Partnering with Solar Turbines, Inc., a turbine housing for a 4.6MW gas turbine was fabricated and deployed at a U.S. Marine Corp. base in California (Fig. 18). Initial operation is expected to begin in October 2013.

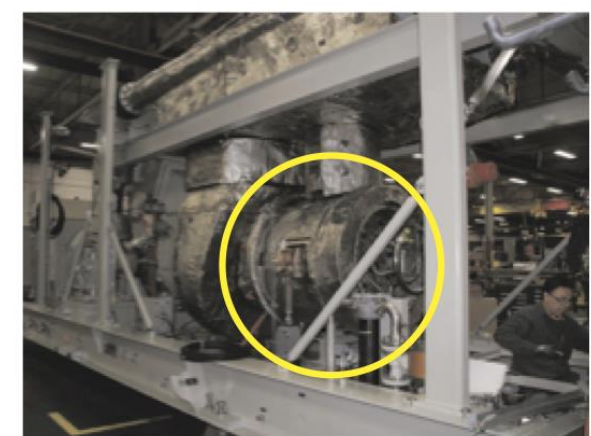

Mercury 50 turbine with CF8C-Plus housing

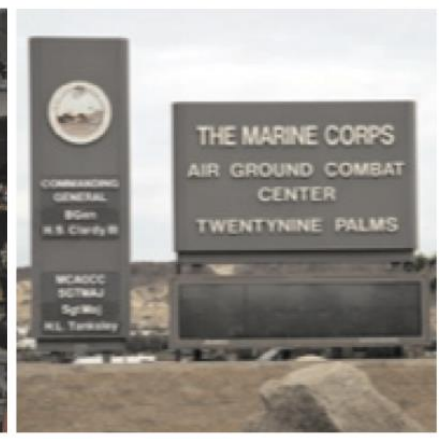

Demonstration site in California

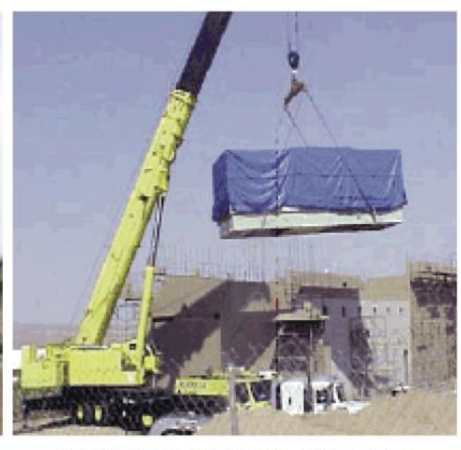

Delivery of Mercury 50 turbine

Fig. 18. Update on the Solar Turbines demonstration at a CHP project in California. The CF8C-Plus housing is circled in the picture on the left.

An ASME Boiler and Pressure Vessel code case was initiated for CF8C-Plus, tensile data package collection was completed and $35 \%$ of the creep data needed for the code case was completed (Fig. 19). CF8C-Plus has been added to a number of relevant ASTM specifications. Completion of the code case for operation to $816^{\circ} \mathrm{C}$ is expected in 2015 with funding from the DOE Office of Fossil Energy. The three commercial batches of CF8C-Plus showed higher creep strength than previous data, however, this extended the time necessary to complete the data collection.

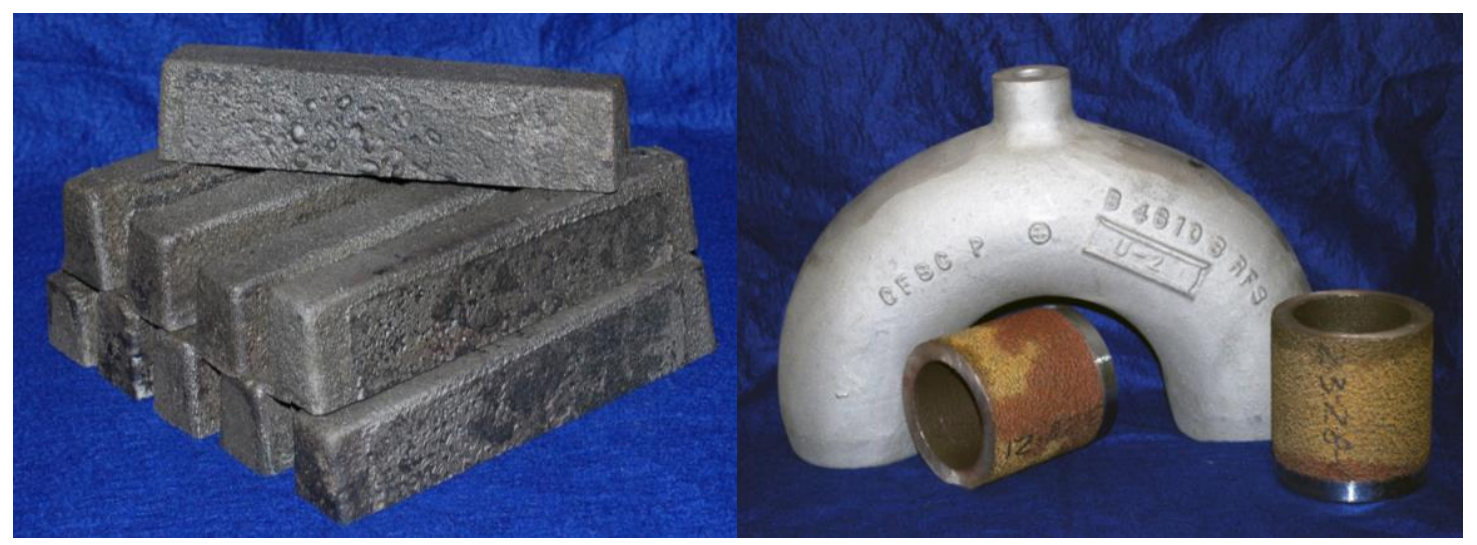

Fig. 19. Keel bars and tube sections from the two commercial orders of CF8C-Plus.

An expanded database was developed for CF8C-Plus and $\mathrm{Cu} / \mathrm{W}$-modified CF8C-Plus including additional cross-weld creep data, fatigue data at $600^{\circ}-900^{\circ} \mathrm{C}$ and environmental resistance data at $650^{\circ}-800^{\circ} \mathrm{C}$. The weld data for CF8C-Plus showed no debit for the weld. The oxidation results at $750^{\circ}-800^{\circ} \mathrm{C}$ confirmed that an oxidation resistant coating is needed at these temperatures for CF8CPlus, especially in the presence of water vapor, such as diesel exhaust. 
New alloy compositions were investigated with higher $\mathrm{Cr}$ and $\mathrm{Ni}$ contents to improve the high temperature oxidation resistance. Compared to the base alloy with $\mathrm{Cu}$ and $\mathrm{W}$, increasing the $\mathrm{Cr}$ and $\mathrm{Ni}$ contents did improve oxidation resistance by a factor of more than 10 but reduced the high temperature creep strength compared to the baseline alloy with $\mathrm{Cu} / \mathrm{W}$. Compared to CF8C-Plus (no $\mathrm{Cu}$ and W additions), the new alloys showed higher creep strength in some conditions and may be further developed for applications where corrosion resistance is critical.

The performance of laboratory and commercial aluminide coatings was evaluated in oxidation testing at $800^{\circ} \mathrm{C}$ and fatigue testing at $800^{\circ} \mathrm{C}$. Significant improvements in oxidation resistance could be attained without reducing the low cycle fatigue life. One important finding was that the coating heat treatment was very critical for both properties and heat treatments of $>1000^{\circ} \mathrm{C}$ were needed to retain the high creep strength of CF8C-Plus.

\subsection{MATERIALS AND PROCESSING FOR ADVANCED BATTERIES}

The primary objective of this ARRA project was to develop advanced, low-cost materials and components processing methods to assist the burgeoning domestic lithium ion battery (LIB) industry and strengthen the associated supply chain, as well as to provide world-class materials characterization for enabling low-cost LIB component commercialization.

Over the course of the A123 CRADA, an anode raw material heat-treatment protocol was developed that optimizes thermal budget and reduces maximum treatment temperature for natural graphite materials. The maximum heat treatment temperature was reduced from well over $2000^{\circ} \mathrm{C}$ for synthetic graphite anodes such as mesoporous carbon microbeads (MCMB) to $1000-1500^{\circ} \mathrm{C}$ with a proprietary gas environment, which translates into $40-50 \%$ reduction in thermal budget (assuming $10^{\circ} \mathrm{C} / \mathrm{min}$ ramp time and two 2-h temperature holds for the treatment above $2000^{\circ} \mathrm{C}$ ).

During the Dow Kokam CRADA, ORNL provided guidance on electrode formulation chemistry, coating procedures and equipment, drying conditions, and in-line quality control. The project began with making Gen I cathode coatings on ORNL's slot-die coating line in 2010 and ended with ORNL contributing to in-line electrode coating quality control improvements to Dow Kokam's pilot coating line in Lee's Summit, MO in 2012. These improvements focused on implementation of in-line electrode dispersion agglomerate size measurement and understanding of uniformity of drying temperature distribution in the oven.

Under the Planar Energy Devices CRADA a photonic annealing protocol for LiNixMnyCozAl1-x-yzO2 (NMCA) films was developed utilizing UV/IR radiation. A complete absorption physics model was also developed that describes optimum processing conditions for annealing. Half-cell performance was demonstrated at levels of $3 \times$ the performance of the as-received (stabilized) NMCA material and $33 \%$ of the furnace annealing baseline. Extensive microstructural and compositional analysis was completed throughout the duration of the project to assist in both optimization of the PulseForge 3300 annealing protocols and correlation to half-cell performance.

Under the Porous Power Technologies CRADA the safety of PVDF based separators (polyester nonwoven reinforced with and without ceramic fillers) was verified in terms of shorting resistance, cycle life, electrolyte compatibility, electrode compatibility, and decomposition products. The HPX and HPX-F technologies were ultimately demonstrated by producing a batch of 21 full-active-area (1.2 Ah) cells using the direct coating process, which incorporated all of the major findings of the CRADA. The SYMMETRIX® HPX-F Nanocomposite Separator received a 2013 R\&D 100 award (Fig. 20). 


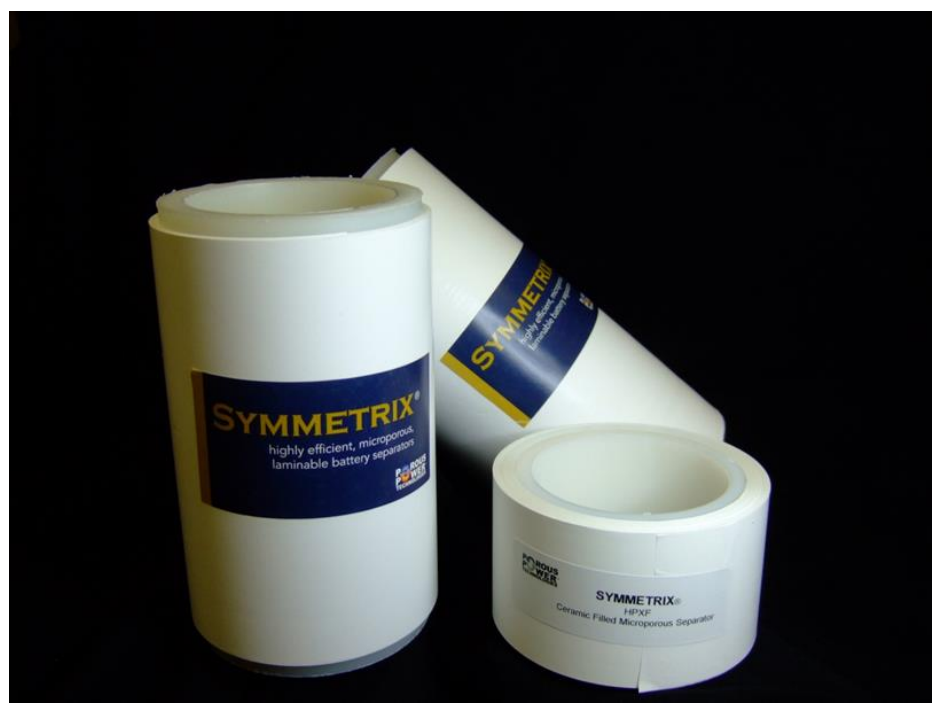

Fig. 20. Rolls of SYMMETRIX ${ }^{\circledR}$ HPX-4 (unfilled) and HPX-F (ceramic-filled) separators for lithium ion batteries.

\subsection{PHOTOVOLTAIC MATERIALS}

The overall approach of the photovoltaic materials project was to leverage ORNL's unique characterization and processing technologies to gain a better understanding of the fundamental challenges for solar cell processing and apply that knowledge to targeted projects with industry members. Four specific projects were pursued with industrial partners: Mossey Creek Solar, for producing low-cost high-quality silicon wafers with significant reductions in waste material and energy consumption; Global Solar Energy, for developing scalable non-vacuum deposition techniques for thin-film copper indium gallium diselenide, a direct-bandgap material for solar cells; Ferro Corp., for developing inks and pastes to be used for highly conductive layers in thin-film solar cell applications; and Ampulse, for developing an efficient roll-to-roll manufacturing process to deposit thin-film silicon.

As part of this project, ORNL also added specific technical equipment to enhance the laboratory's ability to provide unique insight for the solar industry and also conducted research that could be applied to the advanced manufacturing of solar cells.

ORNL conducted various measurements using light beam induced current (LBIC) and photoluminescence (PL) to investigate the impact of internal defects on solar cell performance. ORNL also looked at non-vacuum, low-cost approaches for the manufacture of CIGS and CdTe solar cells using a novel nanoparticle synthesis route as well as room temperature sputtering of material (Fig. 21 and 22). 

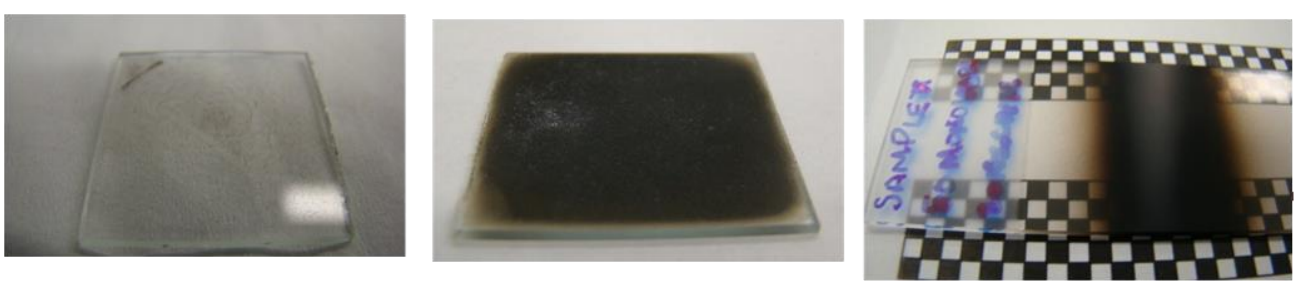

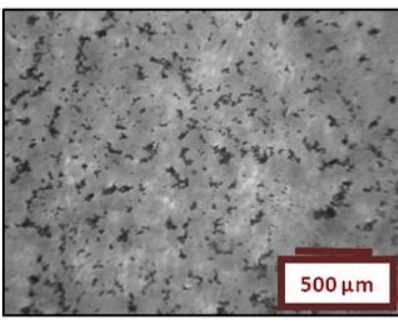

Spin Coating

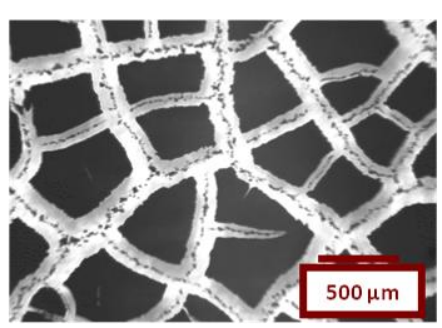

Drop Casting

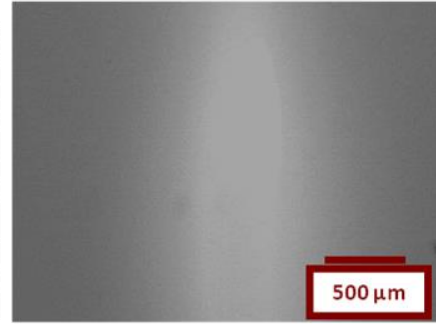

Sono-Deposition

Fig. 21. Top row: digital images of CIGS films acquired via different deposition techniques: spin coating, drop casting, and sono-spray deposition. Bottom row: microscope images showing the morphology of the films over a $2.5 \mathrm{~mm}$ square area.

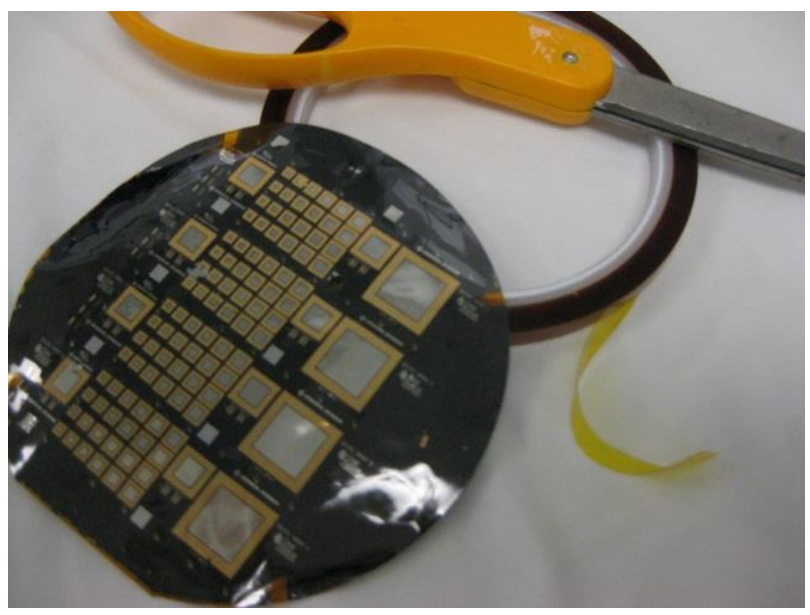

Fig. 22. CdTe thin film solar device array on Kapton disc.

\subsection{MAGNETIC PROCESSING OF STEEL STRIP AND NEXT GENERATION ALLOYS}

In this project high magnetic field processing was applied in two separate process configurations. In the first configuration, a laboratory-scale continuous razor blade processing line incorporating ORNL's ambient temperature high magnetic field was successfully demonstrated. This facility simulated a critical portion of a high temperature heat-treatment razor blade material processing line and demonstrated that a costly and energy inefficient cryogenic cooling processing to control retained austenite could be eliminated with an ambient temperature magnetic process. Magnetic processing resulted in improved process energy efficiency, reduced microstructural variability in the final product, and higher hardness for better performance than currently employed cryogenic commercial processing.

For the razor blade application, a series of refined experimental matrices on the newly commissioned equipment were conducted and analyzed. Besides the energy-efficient 9 tesla, 5 -inch diameter horizontal bore superconducting magnet component, a custom horizontal clamshell 3-zone tube 
furnace was incorporated into the system. The three zones were tuned in order to provide a precise laboratory scale thermal profile of a razor blade production line heat treating thermal profile to control essential carbide volume fraction and minimize retained austenite present in the final product for optimal high strength, durability, and reliability. A continuous steel strip feed system was an integral component providing dynamic feedback for speed and line tension control. This unique tensioning system facilitated effective precision simulation of a high speed manufacturing process in a laboratory scale.

The experimental testing involving production-environment-like continuous processing simulations resulted in defining the impact of the two main processing parameters: 1.) the interrelation between the solution treatment time and the resulting microstructures, especially carbide volume fraction, and, 2.) the effect of the production-line chilled quench block temperature at the exit of the furnace assembly on the resulting microstructure with and without magnetic processing. Microstructural analysis revealed that high magnetic field processing produces materials that are microstructurally more consistent resulting in less process variability in the final product. Essentially, in this application, magnetic processing was shown to reduce the variation in materials with microstructures differing by over $5 \% \mathrm{wt} \%$ retained austenite down to less than one percent.

High magnetic field processing was also combined with induction heating in the second configuration to treat typical power system industrial pump and transportation drive train components (Fig. 23). This work was targeted at completing system validation of a previously developed commercial scale prototype high magnetic field processing system (Fig. 24). This system is the first of its kind and incorporates several novel design concepts for system durability. The system was shown to be an industrially robust design capable of handling the demands on all of the components to meet the high throughput requirements of an industrial environment. This commercial prototype is comprised of a 2000-pound force extraction/sample handling system involving sample rotation during heating and quenching that is integrated around a 9 tesla, $\sim 8$-inch diameter vertical bore superconducting magnet system with a $200 \mathrm{KW}(10-30 \mathrm{KHz})$ induction heating power supply and an in-bore $75 \mathrm{gpm}$ quenching system. Because of the high forces exerted on the high magnetic field superconducting solenoid coils during ferromagnetic sample insertion into the bore of the prototype system and the possibility of magnet quenching (loss of superconductivity due to temperature rise) due to inherent system component interactions, a series of critical experiments were conducted to prove commercial viability. These tests showed that relatively large commercial components (several pound ferrous alloy samples [e.g., orbital drive or gear] which would have a maximum extraction force up to 2000 pounds exerted on them) can be inserted and extracted rapidly at up to 10 inches per second with multiple cycles (up to 45 were demonstrated) while under a 9 tesla magnetic field without causing any negative power changes in or quenching of the magnet solenoid. Tests under induction heating power were similarly conducted with no negative impact. These experiments provided critical data required by our technology commercialization partners AjaxTOCCO Magnethermic (ATM) and American Magnetics Inc. (AMI) to successfully design future next generation commercial prototype superconducting magnet systems incorporating induction heating systems for industrial applications at production rate speeds. This project has not identified any high magnetic field or magnetic quench related equipment issues for ORNL's commercial prototype system that might limit its application for a broad range of typical ferrous alloy component applications within the existing magnet bore size constraints. 


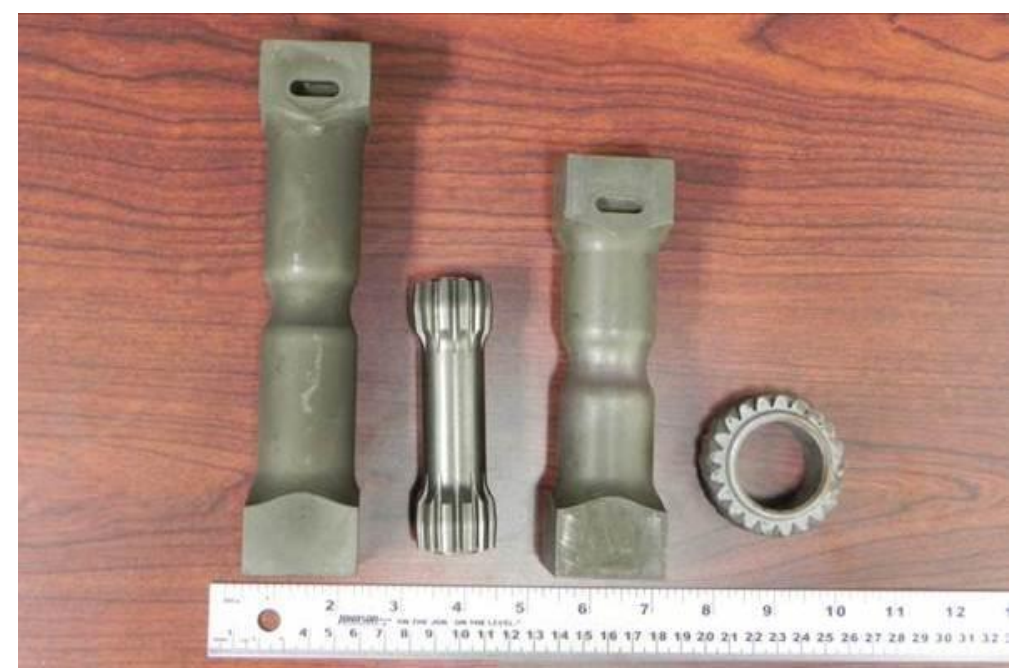

Fig. 23. Typical ferrous alloy components (left to right: large torsion fatigue sample, orbital drive, small torsion fatigue sample, gear) that would need to be handled by the commercial prototype system at insertion rates up to 10 inches/s while under a 9 tesla magnet field.

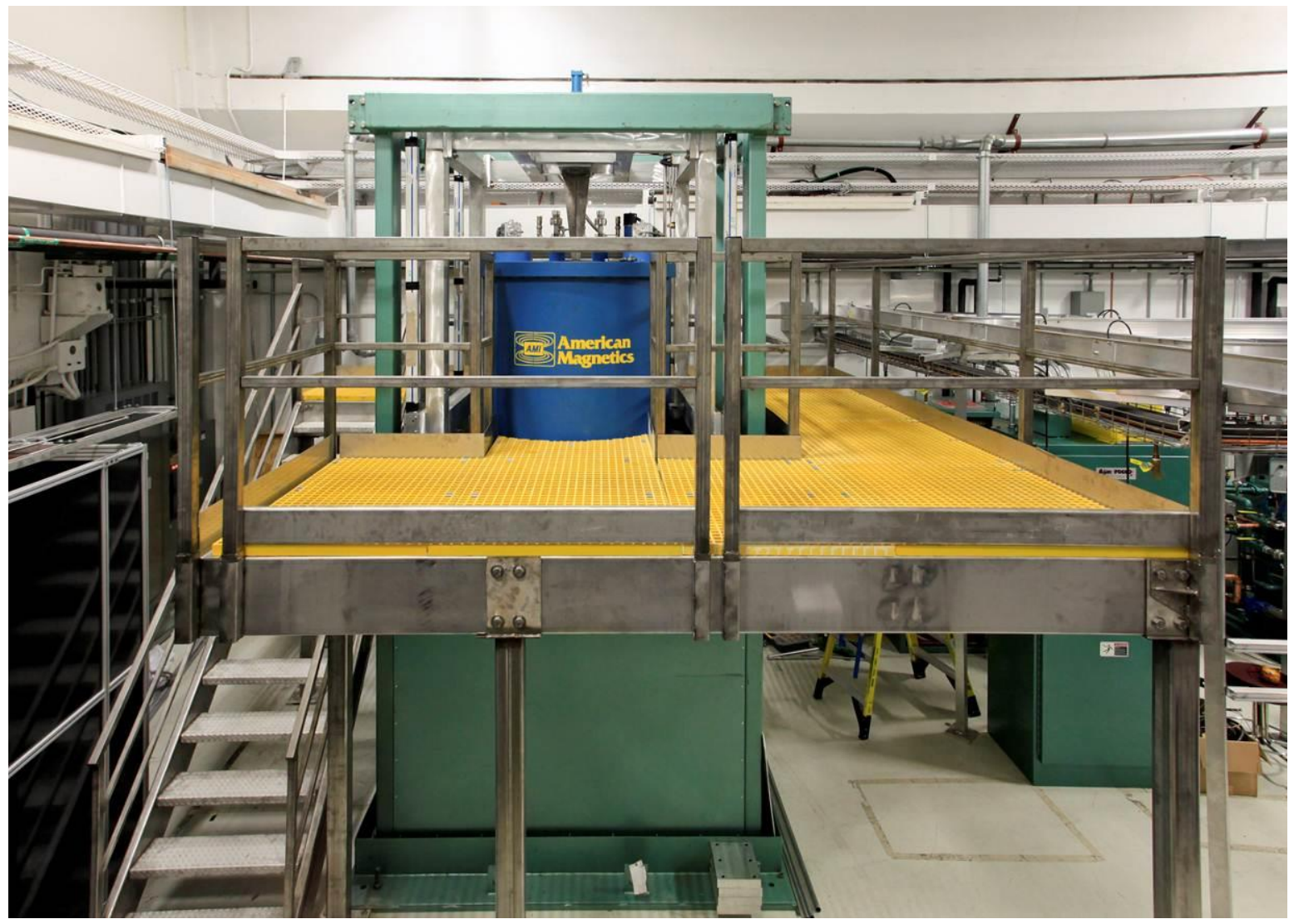

Fig. 24. World's first commercial prototype H\&TMP/EMAT system with an $\sim 8$-inch diameter, vertical warm bore superconducting magnet system and $200 \mathrm{KW}$ dual-frequency induction heating system. 


\section{COMMERCIALIZATION}

Commercialization activities for the Advanced Materials in Support of EERE Needs to Advance Clean Energy Technologies Program are discussed in the individual final reports for each of these technologies. Brief summaries are presented below.

The titanium project demonstrated that flat plate sheet for heat exchangers can be made from titanium powder and successfully used in a subscale heat exchanger. However, several barriers exist for producing titanium sheet via powder metallurgy. At the start of this project, the market conditions were trending toward high prices and long deliveries for Kroll processed titanium sheet, making the prospect of a more stably priced powder metallurgy source that was decoupled from the aerospace market more attractive. By the end of the project, titanium sheet produced via the Kroll process was readily available, with acceptable price and delivery, retarding industrial interest in powder metallurgy titanium.

Based upon the developments achieved in the magnesium project, a new commercial scale asymmetric rolling mill with warm rolls for isothermal rolling has been made available for purchase by FATA Hunter. The design for FATA Hunter's pilot scale shear rolling mill received an R\&D 100 award in 2012. Textural modification of magnesium sheet through shear rolling was demonstrated showing a path increased $\mathrm{Mg}$ sheet applications through improved formability industrial scale production technology.

Based upon the developments achieved in the carbon fiber project, a plan was developed for the commercialization of LBCF thermal insulation, with key milestones including evaluation of multiple scalable lignin sources in 2013, tons-scale production and field testing by customers in 2014 , and product launch as soon thereafter as production capabilities can be constructed and commissioned.

Multiple scale up and commercial demonstration activities related to commercialization of AFA alloys were pursued, with an emphasis on gas turbine recuperator and heat exchanger applications. Formal projects were completed with United Technologies Corp. and Capstone Turbine Corp. and cost-share was also obtained on collaborations with Carpenter Technology Corp. (CTC), Duraloy Technologies and Solar Turbines. AFA material was successfully produced in strip, foil, and tube form, including a successful 10,000lb production heat by CTC, which licensed the AFA alloy patents in 2011. A database was completed for a baseline AFA alloy that was summarized in an alloy data sheet which included mechanical properties, high-temperature corrosion resistance, joining characteristics, and thermo-physical properties needed by potential industrial end users to assess AFA. Several new grades of AFA alloy also were developed, including a cast form of AFA with a promising combination of creep and oxidation resistance. A patent was awarded for cast AFA and it was successfully centrifugally cast in tube form by an industrial collaborator. Evaluation of AFA alloys by industrial collaborators, as well as marketing and scale up activities by CTC will continue beyond the conclusion of this project as various AFA alloy compositions continue to progress into commercial applications.

Oak Ridge National Laboratory and Caterpillar jointly hold the patent for CF8C-Plus. Trial and commercial licenses are available to interested casting companies and end-users by either company. Currently, Stainless Foundry \& Engineering (SF\&E) in Milwaukee, WI has a commercial license for casting CF8C-Plus, and has produced the keel bars for that project. SF\&E in the past produced prototype CF8C-Plus exhaust components for Waukesha Engine, Dresser natural gas reciprocating engines that were field-tested and found to work well. 
The Solar Turbines, Inc. commercial demonstration of a CF8C-Plus turbine housing in a 4.6MW Mercury 50 engine was sited at an expansion of a CHP installation at the U.S. Marine Corp. Base in 29 Palms, California. Commercial operation of this facility is expected to begin in October 2013 after unexpected delays. The housing will be monitored during field service and inspected after 90 days of operation followed by indefinite continued operation. Hopefully, this demonstration and associated data collection will enable future turbine designs and other turbine manufacturers to take full advantage of the excellent properties of CF8C-Plus. The defect-free air-melt casting of CF8C-Plus steel demonstrated the excellent castability (and metal fluidity) of this alloy.

Based on the results of the advanced batteries project, U.S. Patent Application No. 13/596,291 covering the anode raw material heat-treatment protocol was filed on 8/20/12 with joint inventors and assignees between ORNL and A123 Systems. Information about electrode formulation chemistry, coating procedures and equipment, drying conditions, and in-line quality control was integrated over the course of the project into the Dow Kokam pilot electrode coating line in Lee's Summit, MO. The Planar Energy Devices CRADA resulted in a patent application for a photonic annealing protocol. Porous Power Technologies' SYMMETRIX ${ }^{\circledR}$ HPX-F Nanocomposite Separator was commercialized and received a $2013 \mathrm{R} \& \mathrm{D} 100$ award.

The four CRADA projects in the photovoltaic materials project were successfully completed advancing production of low-cost high-quality silicon wafers, developing scalable non-vacuum deposition techniques for thin-film copper indium gallium diselenide, developing inks and pastes to be used for highly conductive layers in thin-film solar cell applications, and developing an efficient rollto-roll manufacturing process to deposit thin-film silicon.

A laboratory-scale continuous razor blade processing line incorporating ORNL's ambient temperature high magnetic field technology was successfully demonstrated during the magnetic field processing project. This facility simulated a critical portion of a high temperature heat-treatment razor blade material processing line and demonstrated that a costly and energy inefficient cryogenic cooling processing to control retained austenite could be eliminated with an ambient temperature magnetic process. Magnetic processing resulted in improved process energy efficiency, reduced microstructural variability in the final product, and higher hardness for better performance than currently employed cryogenic commercial processing. Therefore, high magnetic field processing incorporated into a razor strip production line was shown to be a technically-feasible, commercially-viable approach to making a superior blade razor product. However, ORNL's industrial partner was acquired during the project and the new parent company elected to not continue the project.

High magnetic field processing was combined with induction heating in a second configuration to treat typical power system industrial pump and transportation drive train components. This work was targeted at completing system validation of a previously developed commercial scale prototype high magnetic field processing system. This system is the first of its kind and incorporates several novel design concepts for system durability. The system was shown to be an industrially robust design capable of handling the demands on all of the components to meet the high throughput requirements of an industrial environment. These experiments provided critical data required by our technology commercialization partners AjaxTOCCO Magnethermic (ATM) and American Magnetics Inc. (AMI) to successfully design future next generation commercial prototype superconducting magnet systems incorporating induction heating systems for industrial applications at production rate speeds. 


\section{ACCOMPLISHMENTS}

The major accomplishments for the projects managed under this activity are summarized below.

Results from the titanium project demonstrated that titanium sheet from powder could be produced via roll compaction and thermomechanical deformation by three different processing routes. Sheet was produced from $\mathrm{HDH}$ titanium powder following one of the processing routes using a multi-company commercial infrastructure. The sheet was tested for mechanical performance and installed in a prototype heat exchanger for a short duration test and was found to adequately exchange heat.

Results from the magnesium project clearly demonstrated that texture modification can be achieved through shear rolling and that the shear rolling process is amenable to high throughput industrial processing. This textural modification was identified as the key to improving the formability of magnesium sheet modification of the predominantly basal texture that develops in magnesium alloy sheets due to traditional casting and rolling techniques. Two demonstrative automotive parts were fabricated.

In the carbon fiber project, LBCF thermal insulation prototypes were produced at two scales with both meeting performance evaluation criteria. During production of the insulation prototypes, ORNL and GrafTech demonstrated lignin compounding/pelletization, fiber production, heat treatment, and compositing at scales far surpassing those previously demonstrated in LBCF R\&D or production.

$>$ First lignin pellet production, meeting fiber extrusion requirements, at scale $>10 \mathrm{lb}$

$>$ First lignin fiber production at scale $>10 \mathrm{lb}$

$>$ First production of melt blown web from lignin

$>$ First lignin fiber stabilization at scale $>1 \mathrm{lb}$

$>$ First lignin fiber carbonization at scale $>1 \mathrm{lb}$

$>$ First production of LBCF composite articles at $1 \mathrm{ft}^{3}$ scale

The three core AFA alloy family patent portfolio was licensed by Carpenter Technologies Corporation on April 7, 2011. Manufacture of AFA on a commercial production scale was demonstrated by a successful 10,000 lb heat by Carpenter and a $2300 \mathrm{lb}$ heat by MetalWerks. Manufacturing protocols to process this material in strip, foil, wire, and tube form were developed. The ability to manufacture AFA foil into air cell recuperator form was demonstrated by Capstone Turbine Corporation and Solar Turbines, Inc. Engine testing of these cells will be pursued in 2013 and 2014. Evaluation of AFA for solid oxide fuel cell heat exchanger applications by UTRC/UConn found promising low rates of $\mathrm{Cr}$ release (Cr contamination can degrade SOFC stacks). UTRC was further able to demonstrate that AFA foil was amenable to brazing needed for heat exchanger manufacture. Duraloy Technologies Inc. successfully manufactured $\sim 4.7 \mathrm{~m}$ long tubes with a 95mm OD and $\sim 16 \mathrm{~mm}$ wall thickness using established centrifugal casting techniques form a cast AFA grade developed under Task 4 of this effort.

A database was developed for the baseline AFA grade OC-4 alloy with characterization for thermal expansion, thermal conductivity, modulus, tensile strength (solution annealed and aged), low cycle fatigue (solution annealed and aged), creep resistance and high-temperature oxidation and corrosion resistance. This data is needed by designers for their assessment of AFA alloys. Creep and oxidation/corrosion test data for OC-4 in plate and foil form, with some conditions exceeding $5000 \mathrm{~h}$ 
duration were generated. Creep studies of welded OC-4 indicated creep strength comparable to the base material, with only a small weld creep rupture life reduction factor.

Higher temperature capable $\mathrm{AFA}^{\mathrm{HP}}$ grade alloys were successfully developed which resulted in $950^{\circ} \mathrm{C}$ range capability (includes contributions from related CRADA effort with Carpenter).

A new grade of AFA alloys amenable to casting was successfully developed: Cast Alumina Forming Austenitic Stainless Steels, US 8,431,072 B2 Apr. 30, 2013. Tube manufacture was successfully demonstrated by Duraloy.

In the CF8C-Plus project in partnership with Solar Turbines Inc. a CF8C-Plus turbine combustor housing was cast. A Mercury 50 turbine with a CF8C-Plus housing was delivered to the construction site at the U.S. Marine Corp Base at 29 Palms, California. A tensile data set was completed for the time-independent portion of the CF8C-Plus Boiler and pressure vessel code case and was presented to the ASME committee in May 2012. CF8C-Plus was added to ASTM specifications A297/A297M-10 and A488/A488M-10 and ballots are being prepared for A743/A743M-12 and A351/A351M-12b.

In property database development for CF8C-Plus, cross-weld creep testing was completed showing no debit in creep life for CF8C-Plus. Fatigue testing was completed at $600^{\circ}-900^{\circ} \mathrm{C}$ on $\mathrm{CF} 8 \mathrm{C}$-Plus and comparison with the W/Cu modified CF8C-Plus showed that the higher creep strength in the modified alloy reduced the fatigue life. The comparison of the environmental resistance of CF8C-Plus and CF8C-Plus modified with $\mathrm{W}$ and $\mathrm{Cu}$ was completed showing enhanced oxidation resistance of the alloy with $\mathrm{W}$ and $\mathrm{Cu}$. The environmental testing at $750^{\circ}-800^{\circ} \mathrm{C}$ confirmed that the $\mathrm{Mn}$ and $\mathrm{N}$ additions that improve creep strength do not significantly improve oxidation resistance, thus the need for a protective coating.

Two new alloy compositions of CF8C-Plus with higher $\mathrm{Cr}$ and Ni contents and the same $\mathrm{Cu}$ and W additions were selected based on thermodynamic computational work and were commercially cast and evaluated. Laboratory and commercial Al-rich coatings were shown to improve oxidation resistance at $800^{\circ} \mathrm{C}$ in wet air, a condition where the uncoated CF8C-Plus has excellent creep strength but poor oxidation resistance. The coating task demonstrated several coating options that greatly improved the oxidation resistance of CF8C-Plus without a significant reduction in the low cycle fatigue behavior at $800^{\circ}$ and $900^{\circ} \mathrm{C}$. The heat treatment of the coating was found to be critical in maintaining the mechanical properties of the substrate.

The advanced battery project successfully executed four CRADAs with industrial partners on different aspects of advanced batteries. This work developed an anode raw material heat-treatment protocol that optimizes thermal budget and reduces maximum treatment temperature for natural graphite materials, now covered by a new patent application. ORNL provided guidance on electrode formulation chemistry, coating procedures and equipment, drying conditions, and in-line quality control that was integrated into an industrial pilot line. A photonic annealing protocol for LiNixMnyCozAl1-x-y-zO2 (NMCA) films was developed utilizing UV/IR radiation was developed that resulted in a patent application. The safety of the PVDF based separators The HPX and HPX-F technologies were ultimately demonstrated and commercialized. The SYMMETRIX® HPX-F Nanocomposite Separator received a $2013 R \& D 100$ award.

The photovoltaic materials project successfully executed four CRADAs with industrial partners on a variety of candidate materials for PV devices. ORNL also conducted fundamental research relevant to the manufacture and improved performance of solar cell technologies. ORNL conducted various measurements using light beam induced current (LBIC) and photoluminescence (PL) to investigate the 
impact of internal defects on solar cell performance. ORNL also looked at non-vacuum, low-cost approaches for the manufacture of CIGS and CdTe solar cells using a novel nanoparticle synthesis route as well as room temperature sputtering of material.

A laboratory-scale continuous razor blade processing line incorporating ORNL's ambient temperature high magnetic field technology was successfully demonstrated during the project. Magnetic processing resulted in improved process energy efficiency, reduced microstructural variability in the final product, and higher hardness for better performance than currently employed cryogenic commercial processing. In this razor blade application, magnetic processing was shown to reduce the variation in materials with microstructures differing by over $5 \% \mathrm{wt} \%$ retained austenite down to less than a percent.

The ITMP prototype system is the first of its kind and incorporates several novel design concepts for system durability. This commercial prototype is comprised of a 2000-pound force extraction/sample handling system involving sample rotation during heating and quenching that is integrated around a 9 tesla, 8-inch diameter vertical bore superconducting magnet system with a $200 \mathrm{KW}(10-30 \mathrm{KHz})$ induction heating power supply and an in-bore $75 \mathrm{gpm}$ quenching system. Because of the high forces exerted on the high magnetic field superconducting solenoid coils during ferromagnetic sample insertion into the bore of the prototype system and the possibility of magnet quenching (loss of superconductivity due to temperature rise) due to inherent system component interactions, a series of critical experiments were conducted to prove commercial viability in the project. These tests showed that relatively large commercial components (several pound ferrous alloy samples [e.g., orbital drive or gear] which would have a maximum extraction force up to 2000 pounds exerted on them) can be inserted and extracted rapidly at up to 10 inches per second with multiple cycles (up to 45 were demonstrated) while under a 9 tesla magnetic field without causing any negative power changes or quenching of the magnet solenoid.

\subsection{PUBLICATIONS AND PRESENTATIONS}

None associated with this task. Publications and presentations resulting from each of the research and development activities are detailed in the final reports for those projects.

\subsection{INTELLECTUAL PROPERY}

Table 1. ORNL Invention Disclosures Carbon Fiber Project

\begin{tabular}{|l|l|l|l|}
\hline $\begin{array}{l}\text { ID } / \\
\text { Patent \# }\end{array}$ & Inventor & Title & Status \\
\hline 2778 & Nunnery et. al. & High speed melt spinning of multi-filament lignin & $\begin{array}{l}\text { Disclosed } \\
12-30-11\end{array}$ \\
\hline 2779 & Nunnery et. al. & Compounding and pelletization of lignin & $\begin{array}{l}\text { Disclosed } \\
12-30-11\end{array}$ \\
\hline 2780 & Nunnery et. al. & $\begin{array}{l}\text { Novel compositions for lignin-based carbon fiber } \\
\text { formation optimization }\end{array}$ & $\begin{array}{l}\text { Disclosed } \\
12-30-11\end{array}$ \\
\hline 2781 & Nunnery et. al. & High-rate Melt-blown Processing of Lignin Fibers & $\begin{array}{l}\text { Disclosed } \\
12-30-11\end{array}$ \\
\hline 2782 & Nunnery et. al. & $\begin{array}{l}\text { Isotropic Lignin-Based Carbon Fibers with Low } \\
\text { Transport Properties }\end{array}$ & $\begin{array}{l}\text { Disclosed } \\
12-30-11\end{array}$ \\
\hline 2891 & $\begin{array}{l}\text { Nunnery \& } \\
\text { Webb }\end{array}$ & Lignin-based hollow carbon fibers & $\begin{array}{l}\text { Disclosed } \\
6-27-12\end{array}$ \\
\hline 2892 & $\begin{array}{l}\text { Nunnery \& } \\
\text { Webb }\end{array}$ & $\begin{array}{l}\text { Improved lignin handling for carbon fiber } \\
\text { manufacture }\end{array}$ & $\begin{array}{l}\text { Disclosed } \\
6-27-12\end{array}$ \\
\hline
\end{tabular}


U.S. patent 8,431,072, "Cast Alumina Forming Austenitic Stainless Steels" was issued on April 30, 2013.

The three core AFA patents were licensed by Carpenter Technologies Corporation on April 7, 2011

The following intellectual property was generated through the energy storage project

1. J.A. Angelini, C. Daniel, C.E. Duty, J.Y. Howe, P. Joshi, J. Li, E.A. Payzant, A.S. Sabau, D.L. Wood, and I. Oladeji, "Pulse Thermal Processing of Solid State Lithium Ion Battery Cathodes," Filed December TBD, 2012, U.S. Patent Application No. Unassigned (UT-Battelle, LLC).

2. B.L. Armstrong, C. Daniel, D.L. Wood, and J. Li, "Aqueous Processing of Composite Lithium Ion Electrode Material," Filed October 12th, 2012, U.S. Patent Application No. 13/651,270 (UTBattelle, LLC).

3. C.I. Contescu, N.C. Gallego, J.Y. Howe, H.M. Meyer, III, E.A. Payzant, D.L. Wood, III, S.Y. Yoon, and M.R. Denlinger, "Forming Gas Treatment of Lithium Ion Battery Anode Graphite Powders," Filed August 20th, 2012, U.S. Patent Application No. 13/596,291 (UT-Battelle, LLC).

\subsection{AWARDS}

Two R\&D 100 awards were received by ORNL and its industrial partners as a result of activities conducted under this activity. Under the magnesium work, a new laboratory scale asymmetric rolling mill with warm rolls for isothermal rolling was designed and fabricated to enable asymmetric rolling of magnesium alloy sheets. "Asymmetric Rolling Mill: A Novel Route for Processing Sheet and Plate" submitted by Fata Hunter Inc., ORNL and Magnesium Elekron North America won an R \& D 100 award in 2012 for an innovative rolling mill designed to process metal sheet and plate to required thickness using heated rolls rotating at different relative velocities, thereby imparting unique properties.

Novel SYMMETRIX® HPX-F Nanocomposite Separator for Improved Lithium Ion Battery Safety” submitted by Porous Power Technologies, LLC and ORNL won an R\&D 100 award in 2013 for a lithium ion battery nanocomposite separator for improved safety and long-term reliability.

In addition, the AFA and CF8C-Plus alloys targeted for accelerated commercialization under this activity had previously received R\&D 100 awards. 


\section{REFERENCES}

Titanium Sheet Production from Commercial Powder, Thomas R. Muth, William H. Peter, Yukinori Yamamoto, Wei Chen, David Harper, Kevin Harper, Greg Cox, and Larry Lowe, ORNL TM$2012 / 534$

Shear Rolling of Magnesium Sheet for Automotive, Defense, and Energy Applications, G. Muralidharan, T. R. Muth, William H. Peter, T. R. Watkins, E. Ohriner, and Y. Wang, Dave Randman, Bruce Davis, Marytn Alderman, and Chris Romanoski, ORNL/TM-2012/541

Commercialization of New Carbon Fiber Materials Based on Sustainable Resources for Energy Applications, Cliff Eberle, Tracy Albers, Chong Chen, and Daniel Webb, ORNL/TM-2013/54

Deployment of Alumina Forming Austenitic (AFA) Stainless Steel, Bruce A. Pint, Michael P. Brady, Yukinori Yamamoto, Govindarajan Muralidharan, and Hiram Rogers, AFA ORNL/TM-2013/479

Deployment of CF8C-Plus Cast Stainless Steels, Bruce A. Pint, Mark D. Lipschutz, and Ying Zhang, ORNL/TM-2013/277

Materials and Processing for Advanced Batteries, David L. Wood, III, ORNL/TM-2012/561

Photovoltaic Materials, Chad Duty, Joseph Angelini, Beth Armstrong, Charlee Bennett, Boyd Evans, Gerald E. Jellison, Pooran Joshi, Fred List, Parans Paranthaman, Chad Parish, and Andrew Wereszczak, ORNL/TM-2012/449

Magnetic Processing of Steel Strip and Next Generation Alloys, Gerard (Gerry) M. Ludtka, Gail Mackiewicz Ludtka, Orlando Rios, John B. Wilgen, Chad M. Parish, Hiram Rogers, Roger A. Kisner, Don M. Nicholson, Tom Watkins, Alexandru Stoica, David White, and Bart L. Murphy, ORNL/TM2012/608 